\title{
PREPARING FOR THE FUTURE, LOOKING TO THE PAST: HISTORY, THEORY, AND DOCTRINE IN THE U.S. ARMY
}

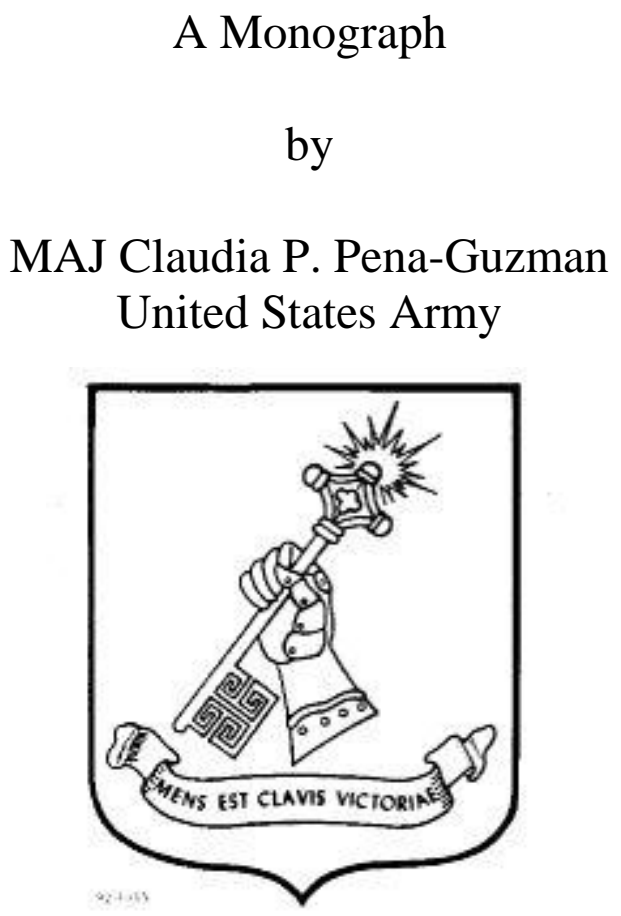

School of Advanced Military Studies

United States Army Command and General Staff College

Fort Leavenworth, Kansas

2013-01

Approved for public release; distribution is unlimited. 


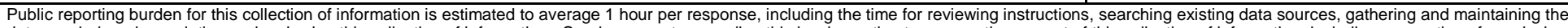

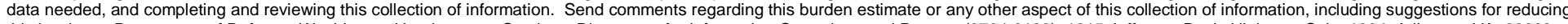

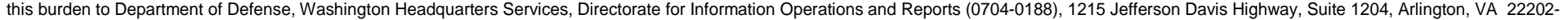

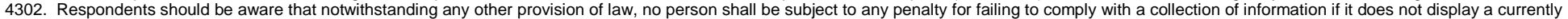

valid OMB control number. PLEASE DO NOT RETURN YOUR FORM TO THE ABOVE ADDRESS.

1. REPORT DATE (DD-MM-YYYY) $\quad$ 2. REPORT TYPE $\quad$ 3. DATES COVERED (FrOm - TO)

\section{TITLE AND SUBTITLE}

SAMS Monograph

JUNE 2012 - MAY 2013

Preparing for the Future, looking to the Past: History, Theory, and Doctrine in the U.S. Army

5b. GRANT NUMBER

5c. PROGRAM ELEMENT NUMBER

\section{AUTHOR(S)}

MAJ Claudia P. Pena-Guzman

5d. PROJECT NUMBER

5e. TASK NUMBER

5f. WORK UNIT NUMBER

7. PERFORMING ORGANIZATION NAME(S) AND ADDRESS(ES)

U.S. Army School of Advanced Military Studies

8. PERFORMING ORGANIZATION REPORT NUMBER

ATTN: ATZL-SWD-GD

Ft. Leavenworth, KS 66027

9. SPONSORING I MONITORING AGENCY NAME(S) AND ADDRESS(ES)

10. SPONSOR/MONITOR'S ACRONYM(S)

11. SPONSOR/MONITOR'S REPORT NUMBER(S)

12. DISTRIBUTION / AVAILABILITY STATEMENT

Approved for public release; distribution is unlimited.

13. SUPPLEMENTARY NOTES

14. ABSTRACT

See abstract.

\section{SUBJECT TERMS}

Doctrine, theory, military history, FM 100-5, ADP 3-0

16. SECURITY CLASSIFICATION OF:

a. REPORT

(U)

b. ABSTRACT

(U)
17. LIMITATION OF ABSTRACT \begin{tabular}{l|l} 
C. THIS PAGE \\
(U)
\end{tabular}

18. NUMBER
OF PAGES
47

19a. NAME OF RESPONSIBLE PERSON

19b. TELEPHONE NUMBER (include area code) 


\section{MONOGRAPH APPROVAL PAGE}

Name of Candidate: Major Claudia P. Pena-Guzman

Monograph Title: Preparing for the Future, Looking to the Past: History, Theory, and Doctrine in the U.S. Army

Approved by:

Peter J. Schifferle, Ph.D.

, Monograph Director

, Seminar Leader

James E. Barren, COL

, Director, School of Advanced Military Studies

Thomas C. Graves, COL

Accepted this 23rd day of May 2013 by:

Robert F. Baumann, Ph.D.

, Director, Graduate Degree Programs

The opinions and conclusions expressed herein are those of the student author and do not necessarily represent the views of the U.S. Army Command and General Staff College or any other governmental agency. (References to this study should include the foregoing statement.) 


\begin{abstract}
PREPARING FOR THE FUTURE, LOOKING TO THE PAST: HISTORY, THEORY AND DOCTRINE, by Major Claudia P. Pena-Guzman, 47 pages.
\end{abstract}

The Army is in transition reflecting on the experiences from recent combat operations in Iraq and Afghanistan while preparing for "evolving threats." This is not a new predicament. In the past, the Army has been able to effect change by drawing lessons from its experience, from theory, and articulating institutional ideas about the nature of future warfare in doctrine. The most recent evolution of the Army's operations doctrine is Unified Land Operations; however, this doctrine does not explicitly identify a clear threat focus and does not appear to have an explicit overarching theory of war. Without a clear threat focus or an overarching theory of war this raises concerns about the Army's readiness to face future threats. At the U.S. Army Command and General Staff College, officers receive instruction on a viable relationship between history, theory, and doctrine. However, a clear-cut relationship between history, theory, and doctrine development is not evident. In fact, the relationship between history, theory and doctrine development for the U.S. Army operations doctrine today is an iterative, organic process that has not yielded an overarching theory of war.

Analysis of the U.S. Army's FM 100-5 development from 1976 to 1986 illustrated that historically key individuals have influenced the Army's operations doctrine. Often the ideas developed by the key individuals emerged from study of military history, warfare theorists, personal experiences, and lessons learned. The dynamic interactions amongst the diverse sources of influence gave rise to an iterative, organic process similar to Thomas Kuhn's paradigm shift where new paradigms replaced old ones. In the iterative and evolutionary process, history, theory, personal experiences, and lessons learned interacted to create the new paradigm. Once the Army accepted the new paradigm, a rewrite of the doctrine ensued. In rewriting the Army's operations doctrine, FM 100-5, the Army leadership explicitly demonstrated that they knew "why, when, and how" to change to insure the Army remained effective.

In 2013, after eleven years of war against an unanticipated unconventional adversary, the Army once more finds itself debating and theorizing on needed change to face future threats. Because the Army's concept for future warfare does not identify either an explicit threat focus or theory, does not imply the Army will be ill prepared to meet future challenges. The Army will need to assume risk commensurate with the requirements levied against it. No matter what the Army prepares for it will be wrong because of the usual dynamics of friction and chance in warfare. The Army's challenge is to not to be so wrong that it cannot quickly adapt. The Army's operations doctrine must strike a balance such that military professionals can effectively interpret events, guide action and connect tactical actions with strategic purposes to continue to achieve positions of relative advantage. 


\section{ACKNOWLEDGMENTS}

For my husband Ivan, and our three children Miguel, Gabbi and Sophie, your unwavering support was unrivaled, I would not be where I am today without you at my side. Heartfelt thanks to my family and friends for your votes of confidence. Dr. Schifferle, Ed and Todd thank you for guiding the way with your thoughtful inquiry and critique throughout the research process. Dr. Benson, COL Barren, and fellow members of seminar four, thank you for your support throughout the year. 


\section{TABLE OF CONTENTS}

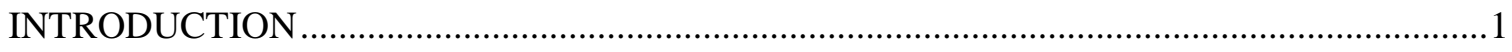

HISTORY, THEORY AND DOCTRINE IN THE U.S. ARMY ….......................................

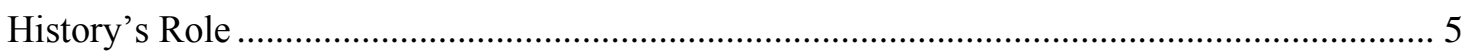

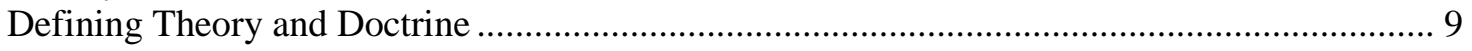

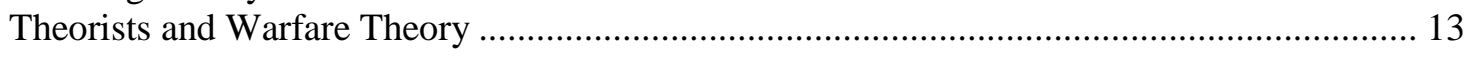

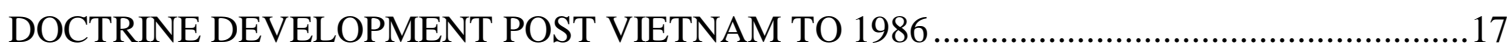

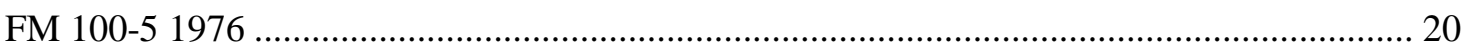

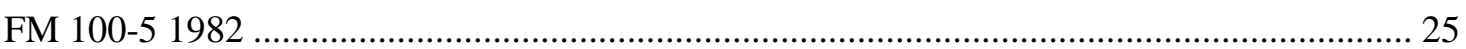

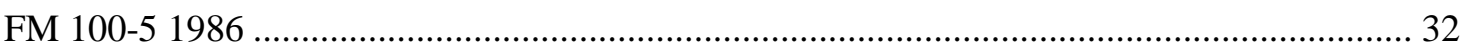

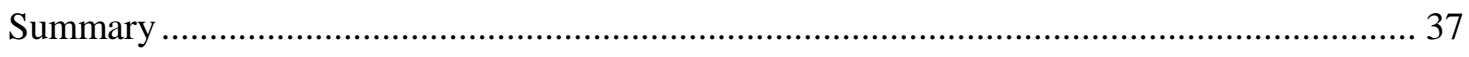

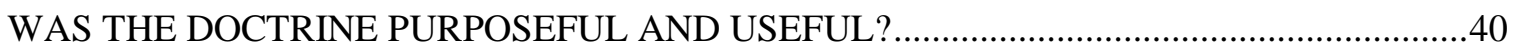

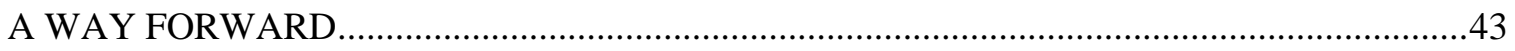

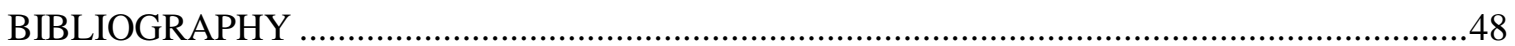




\section{INTRODUCTION}

While we cannot predict the future, we can be certain that our Nation will continue to call on America's Army. Going forward, we will be an Army in transition. An Army that will apply the lessons learned in recent combat as we prepare for evolving threats.

- General Raymond T. Odierno, ADP 1 The Army, 2012

In 1973 after ten years of conflict in Vietnam, the Army was ill prepared to face its most dangerous threat, the Soviet Union and Warsaw Pact, and had little stomach to engage in another drawn out unconventional conflict. In the development of the Active Defense and Airland Battle operations doctrine of the late 1970s and early 1980s, the Army shifted its focus to a combination of firepower-attrition and maneuver-warfare theory based doctrine. In the early Active Defense doctrine of 1973, the Army defined the Soviet Union and the Warsaw Pact as the most dangerous threat to focus their efforts against. ${ }^{1}$ The Active Defense operations doctrine then evolved to the Airland Battle doctrine of the 1980s and over time expanded the Army's focus beyond high intensity conflict against the Soviet Union. In 2013, after eleven years of war against an unanticipated unconventional adversary, the Army once more finds itself debating and theorizing on needed change to face future threats. The most recent evolution of the Army's operations doctrine is Unified Land Operations; however, this doctrine does not explicitly identify a clear threat focus and does not appear to have an explicit overarching theory of war. If the Army's concept for future warfare does not identify an explicit threat focus or theory, will the Army be ill prepared to meet future challenges?

\footnotetext{
${ }^{1}$ Richard M. Swain, "Filling the Void: The Operational Art and the U.S. Army," In Operational Art: Developments in the Theory of War, edited by B.J.C. McKercher and Michael Hennessy (Westport, CT: Praeger, 1996), 166. Hereafter cited as "Filling the Void." Jeffrey W. Long, "The Evolution of U.S. Army Doctrine: From Active Defense to Airland Battle and Beyond." (Fort Leavenworth, KS: U.S. Army Command and General Staff College, 1991), 31, and Robert A. Doughty, "The Evolution of U.S. Army Tactical Doctrine, 1946-1976." Leavenworth Papers 1 (Fort Leavenworth, KS: August 1979), 49.
} 
As the Chief of Staff of the Army stated, the Army is in transition reflecting on the experiences from recent combat operations in Iraq and Afghanistan while preparing for "evolving threats." This is not a new predicament. ${ }^{2}$ In the past, the Army has been able to effect change by drawing lessons from its experience, from theory, and articulating institutional ideas about the nature of future warfare in doctrine. World War I was a revolution in military affairs and from this revolution, the Army drew principles for the updated form of combined arms warfare. ${ }^{3}$

Similarly, the Army drew lessons after World War II, Korea, the Vietnam War and observation of the 1973 Arab-Israeli War resulting in the development of the doctrine of Active Defense in 1976 that evolved into the 1980s Airland Battle doctrine. The Airland Battle doctrine proved indispensable on the battlefield in Desert Storm in 1991. However, is there such a clear-cut relationship between history, theory, and doctrine development? Has such a relationship existed in the past or does such a relationship exist today?

At the U.S. Army Command and General Staff College (CGSC), officers receive instruction on a viable relationship between history, theory, and doctrine. Students at CGSC learn that experience provides the best lessons to the military professional engaged in learning. However, experience includes both personal experience as well as that learned from others and the study of history. At CGSC, military professionals share their personal experiences as well as learn from the collective experiences of thousands of years found in historical accounts. In the 2011 academic year CGSC history curriculum, the focus was on the problem of coping with change in the military experience. Throughout the history course emphasis was placed on observing how military professionals studied history in combination with their contemporary

\footnotetext{
${ }^{2}$ U.S. Department of the Army, Army Doctrine Publication 1, The Army (Washington, DC: Government Printing Office, September 2012), Foreword.

${ }^{3}$ Peter J. Schifferle, America's School for War: Fort Leavenworth, Officer Education, and Victory in World War II (Lawrence, KS: University Press of Kansas, 2010), 6.
} 
context (societies and military institutions). The conclusion was that from the careful study of history within historical context and the officers' own contemporary context, military professionals devised theories for warfare, what warfare may look like and how to wage it in the future. $^{4}$

In simple terms, the main idea of the espoused relationship between history, theory, and doctrine is clear. The military professional learns from history, personal experiences and contemporary context to develop military theories. Then the theories find articulation in doctrine to help address future threats. In hindsight, the CGSC history curriculum presents a simplistic model for the importance of the study of military history. The model highlights history's implications for the development of military organizations and the possible nature of future warfare. If the model holds true, then the organizational ideas, the concepts of the nature of future threats, and the realities of the contemporary environment will likely foment a theory of warfare that will drive doctrine development. However, if the model does not hold true doctrine development will continue based on a combination of experience and lessons learned without an underlying theory of future warfare. In light of the uncertainty about the nature of the future threat, how should the CGSC construct of history, theory, and doctrine provide a guide for a current operations doctrine to parallel the Airland Battle example?

What if any relationship exists between history, theory and doctrine development for the U.S. Army today? In ascertaining the relationship, implications for preparing the Army to face the evolving threats General Odierno spoke about became evident. To ascertain any relationship between history, theory, and doctrine development requires exploration of another period in which the U.S. Army faced uncertainty about its future and the type of conflict it should prepare for. Empirical evidence drawn from the period after the Vietnam War between 1973 and 1986

\footnotetext{
${ }^{4}$ James H. Willbanks, U.S. Army Command and General Staff College, H100 Rise of the Western Way of War Parallel Block (Fort Leavenworth, KS: USACGSC, 2011), vii.
} 
illustrates some parallels between the challenges the Army faced then and those challenges it faces now.

To frame the argument requires a discussion of the relationship between history, theory and doctrine in the United States Army. The argument also requires a common understanding of what theory and doctrine are. The discussion of the relationship between history, theory and doctrine and working definitions of theory and doctrine are in the first section, "History, Theory and Doctrine in the U.S. Army." Additionally in this section, a discussion of the theories and theorists that have influenced Army doctrine development is presented. For empirical evidence that parallels the Army's current doctrine development, it was necessary to assess the general relationship between military theory and doctrine in a different period. Analyses of the role of military theory and doctrine development in the Army from the post-Vietnam era 1973 to 1986, helped to assess the utility of theory in doctrine. Analysis of U.S. Army operations doctrine between 1973 and 1986 as a case study is in section two, "Doctrine Development Post Vietnam to 1986." An evaluation of the three editions of Field Manual 100-5, Operations (FM 100-5) purposefulness and utility to help provide insight into what the Army should be doing to prepare for the future is found in the third section, "Was the Doctrine Purposeful and Useful?" The last section, "A Way Forward," presents possible implications for the United States Army theory and doctrine in light of its recent experience in Iraq and Afghanistan as well as presents recommendations for further study.

\section{HISTORY, THEORY AND DOCTRINE IN THE U.S. ARMY}

Ideas are important. Born or adopted in particular historical circumstances, they affect man's understanding of his world and, therefore, influence behavior. Ideas are joined to form concepts and concepts are merged to form systems intended to achieve particular purposes. In military organizations, when such systems become unified institutional theories of warfighting, they are called doctrine.

- COL (Ret) Richard M. Swain, 1996

What is the relationship between history, theory, and doctrine in the U.S. Army? What is an acceptable working definition of theory? To what extent, if any, does theory influence doctrine 
development? If not as simple as the CGSC history, theory, doctrine model, then what does influence doctrine development in an era of uncertainty? Dr. Richard M. Swain, Colonel, U.S. Army retired, pointed out that there is no direct link from history to theory and doctrine. Rather doctrine arises from influences of the people involved in its development and from the syntheses of ideas toward achieving the purpose of the military. Further, Swain did point out that those ideas could be either born or adopted from particular historical circumstances. For military professionals, those historical circumstances Swain spoke of include their interests, personal professional experiences and education. Indirectly history could play a significant role and influence over institutional theories and doctrine development. ${ }^{5}$ An exploration of history's role toward theory and doctrine development is in the next section. Also in what follows, to build the foundation for the potential relationship between history, theory, and doctrine, useful definitions of theory and doctrine are established. Lastly, a discussion of theory's role and influential theories and theorists on U.S. Army doctrine follows.

\section{History's Role}

In 1907 Captain Matthew Steele, U.S. Army Cavalry officer and instructor in the Department of Military Art at the Army Staff College, Fort Leavenworth Kansas stated, "To study military history is the best, and without the personal experience of commanding in war, the only way to learn the conduct of war." Steele pointed out that history not only highlights the successes but also the mistakes made so that military professionals can "appreciate the reasons why one side lost and the other won." ${ }^{6}$ Nearly a century before, Clausewitz had also come to a similar conclusion on the use of history. Clausewitz stated, "historical examples clarify

${ }^{5}$ Swain, "Filling the Void," 147.

${ }^{6}$ Matthew Steele, "The Conduct of War" (lecture notes, Department of Military Art, Army Staff College, Fort Leavenworth, KS, 1907), 23. 
everything and also provide the best kind of proof in the [art of war.]" Clausewitz further argued that the nature of the art of war is usually only revealed by experience and historical examples can provide the vast majority of experience. Historical examples can help explain an idea, show the application of an idea, support a statement of fact, and make it possible to deduce a doctrine. ${ }^{7}$ To achieve these four possibilities from studying historical examples military professionals must be capable of synthesizing these ideas through critical thinking and inquiry.

Both Williamson Murray, Minerva Fellow at the Naval War College and Professor Emeritus of History at Ohio State University and Richard Hart Sinnreich, former director of the Army School for Advanced Military Studies (SAMS), independent consultant, columnist, and contributor for Army and joint futures studies, argued that immersion in history invites intellectual debate and challenges individual ideas and assumptions. The immersion in history is doubly important for military professionals, Murray and Sinnreich proposed, because history raises more questions, suggests unpleasant possibilities, destroys preferred theories, often forces recognition of unpalatable truths, and compels leaders to "think dispassionately about potential opponents." ${ }^{8}$ The study of history helps military professionals become more skeptical about the problems and circumstances they confront. Knowledge of military history also helps military professionals in their critical thinking skills if through the knowledge gained they learn to think dispassionately, as Sinnreich prescribed.

In Military Effectiveness, Allan Millett, retired Marine Corps Reserve Colonel, specialist in the history of American military policy and 20th century wars and military institutions, found a key aspect for military effectiveness was insight: understanding the situation. Millett pointed out

${ }^{7}$ Carl von Clausewitz, On War. Ed. and trans. Michael Howard and Peter Paret (Princeton: University Press, 1989), 170-71. Hereafter cited as On War.

${ }^{8}$ Williamson Murray and Richard Hart Sinnreich, "Introduction," in The Past as Prologue: the Importance of History to the Military Profession, eds. Williamson Murray and Richard Hart Sinnreich (New York: Cambridge University Press, 2006), 4. 
that the way a military professional gained this necessary insight was through "willing openness to a variety of stimuli, from intellectual curiosity, from observation and reflection" and from studying history. Millett also added the importance of personal experiences in warfare, history in which one has actually participated, toward gaining insight. ${ }^{9}$ To a similar effect Clausewitz wrote that to teach the art of war entirely by historical examples would be a valuable endeavor and the most effective historian to achieve this end would be someone with a "thorough personal experience of war." ${ }^{, 10}$ In addition to the knowledge gained by others' experience, personal experiences make a considerable contribution toward the ideas military professionals formulate about their craft.

However, Sinnreich, Steele, Millett, and Clausewitz also cautioned against of some of the pitfalls of the study of history. Sinnreich particularly warned that in attempting to draw lessons from history "the wider the scope and the higher the level at which military organizations attempt to direct generalization from historical experience, the greater the risk that they will ignore, misinterpret, or accidentally or intentionally distort the essential elements of that experience." 11 Steele advised military professionals to be wary of historians that twist and strain actual campaigns to make them fit the case they may be trying to prove. ${ }^{12}$ Clausewitz also warned

\footnotetext{
${ }^{9}$ Allan R. Millet and Williamson Murray, eds. Military Effectiveness, Volume III: The Second World War (Boston: Allen and Unwin, 1988), 334 and 336. Italics are from the original document. Hereafter cited as Military Effectiveness, Volume III.

${ }^{10}$ Clausewitz, On War, 174.

${ }^{11}$ Richard Hart Sinnreich, "Awkward Partners: Military History and American military Education," in The Past as Prologue: the Importance of History to the Military Profession, eds. Williamson Murray and Richard Hart Sinnreich (New York: Cambridge University Press, 2006), 67.

${ }^{12}$ Matthew Steele, “The Conduct of War" (lecture notes, Department of Military Art, Army Staff College, Fort Leavenworth, KS, 1907), 24.
} 
against the use of military examples to prove a current principle or theory. ${ }^{13}$ Additionally, both John Lewis Gaddis, historian specializing in the Cold War and grand strategy, and Clausewitz cautioned against the use of history without understanding its context. Both Clausewitz and Gaddis prescribed that history tends to lose elements and details leaving behind pieces of unrelated information that can be and are misinterpreted. ${ }^{14}$

From all that Clausewitz, Millett, Sinnreich, Murray, Steele, and other historians and political scientists have offered regarding the study of history the military professional can derive several ideas that are useful for doctrine development. First, through critical thinking and inquiry military professionals can draw out important ideas that can help deduce warfighting doctrine. Second, knowledge of military history invites intellectual debate and challenges individual ideas and assumptions. Third, the study of military history yields experience and helps provide the insight necessary for Millett's concept of military effectiveness. ${ }^{15}$ Lastly, military professionals should not take the lessons of history at face value. Both the context and the content of historical examples can provide ideas that otherwise would not have been considered. To the astute and studious military professional, history plays an import role in influencing his ideas and views toward developing his warfighting doctrine. Sinnreich adds that in the combination of studying theory and history, theory helps formulate questions of history and conversely history helps challenge the assertions of theory. ${ }^{16}$ A clue that the relationship between history and theory is not linear but arises in an iterative process begins to emerge.

${ }^{13}$ Clausewitz, On War, 173.

${ }^{14}$ John L.Gaddis, The Landscape of History (Oxford, NY: Oxford University Press, 2002), 10.

${ }^{15}$ Millet and Murray, Military Effectiveness, Volume III, 334 and 336. Italics are from the original document.

${ }^{16}$ Richard Hart Sinnreich, "Awkward Partners: Military History and American military Education," in The Past as Prologue: the Importance of History to the Military Profession, eds. 


\section{Defining Theory and Doctrine}

We begin with working definitions for both theory and doctrine. Once these definitions are established, then the analysis of what military historians and others had to say about the utility of theory for the military professional follows. There are numerous definitions of theory; a Google search engine word search of "the meaning of theory" yields over one million hits. However, a narrower search in the Merriam Webster online dictionary has six definitions for theory. ${ }^{17}$ For doctrine, the Merriam Webster on line dictionary provides three definitions. ${ }^{18}$

For the purposes of understanding the possible relationship between a warfare theory and doctrine development the Merriam Webster on line dictionary definitions for theory and doctrine are not useful. Ideally, in analyzing U.S. Army doctrine it would be suitable to use theory and doctrine as the Army defines them but there are no definitions for these terms in Army doctrine. ${ }^{19}$

Williamson Murray and Richard Hart Sinnreich (New York: Cambridge University Press, 2006), 63.

${ }^{17}$ Free Merriam Webster Dictionary, http://www.merriam-webster.com/dictionary/theory (accessed February 1, 2013). The first definition states that theory is the analysis of a set of facts in their relation to one another. Abstract thought or speculation also defines theory. A third definition is the general or abstract principles of a body of fact, a science, or an art such as music theory. A belief, policy, or procedure proposed or followed as the basis of action, an ideal or hypothetical set of facts, principles, or circumstances also define theory. Another definition for theory was a plausible or scientifically acceptable general principle or body of principles offered to explain phenomena. The final definition from the Merriam Webster online dictionary defined theory as an hypothesis assumed for the sake of argument or investigation: an unproved assumption; conjecture; a body of theorems presenting a concise systematic view of a subject.

${ }^{1818}$ Free Merriam Webster Dictionary, http://www.merriamwebster.com/dictionary/doctrine?show $=0 \& t=1359917100$ (accessed February 1, 2013). The first two definitions given for doctrine are something taught, a principle (or position) or the body of principles in a branch of knowledge or system of belief, dogma. The last definition for doctrine is a principle of law established through past decisions, a statement of fundamental government policy especially in international relations.

${ }^{19}$ A word search of the Army's 2010 Field Manual 1-02 Operational Terms and Graphics for the definition of the terms "theory" and "doctrine" did not produce a listing with a definition for either. Similarly A word search of the Joint Publication 1-02 Department of Defense Dictionary of Military and Associated Terms for the terms "theory" and "doctrine" only yields a definition for doctrine. 
Additionally, the definitions presented above for theory are too general and do not provide the requisite details to analyze the presence and utility of theory in U.S. Army operations doctrine. Similarly, the previous definitions of doctrine do not provide specificity for what doctrine means to the military profession. Neither the Joint Publication 1-02 Department of Defense Dictionary of Military and Associated Terms (JP 1-02) or the Army Field Manual 1-02 Operational Terms and Graphics define theory. The lack of an explicit definition for theory and doctrine in the Army publications hints at the problematic relationship between history, theory and doctrine in the CGSC model. By not defining the terms in the professional military lexicon, the Army allows for broad interpretations of these concepts and their significance in the profession. JP 1-02 does define doctrine.

JP 1-02 defines doctrine as fundamental principles by which the military forces guide their actions in support of national objectives. JP 1-02 further stipulates that doctrine is authoritative but requires judgment in application. ${ }^{20}$ The JP 1-02 definition for doctrine is useful because this definition recognizes doctrine as subjective to the situation and judgment of the military professional. The JP 1-02 definition explicitly allows that doctrine can change and evolve as the national objectives change and evolve.

For theory, a more useful definition in this argument is Paul David Reynolds' definition of a "set of abstract statements that are considered part of a scientific body of knowledge...in the causal process form." According to Reynolds, the causal process form of a theory is useful for prediction and explanation. ${ }^{21}$ U.S. Army operations doctrine codifies ideas about warfare that ascribe to explain past events and to help predict probable future events. In the case of a military

\footnotetext{
${ }^{20}$ U.S. Joint Chiefs of Staff, Joint Publication 1-02, Department of Defense Dictionary of Military and Associated Terms (Washington D.C.: Government Printing Office, 2011), 104. In the JP 1-O2 definition, doctrine is not dogma unlike in the second Merriam Webster definition.

${ }^{21}$ Paul D. Reynolds, A Primer for Theory Construction (Boston, MA: Allyn \& Bacon, 1971), 5. Hereafter cited as Primer for Theory Construction.
} 
warfare theory, the abstract statements should include ideas about the nature of the threat, the desired purpose and the means available toward achieving the purpose. The significance of using Reynolds' causal process form definition is that this form of theory allows for hypothetical concepts and allows the examination of all consequences including unintended consequences. It is important to note that what a theory does is attempt to describe an idea or concept. In general the utility of a theory includes that the theory can provide a frame of reference to make sense of a complex problem where such frame may not exist. ${ }^{22}$ Theory can also serve as bridge from a current known situation to an unknown but desired situation. As Reynolds pointed out however, theory is not stagnant, theory evolves in all social sciences and the group of interest must accept the theory. It will be more likely that the group will accept the theory if the idea or concept, on warfighting in the case of military professionals, is understood and shared by the group. ${ }^{23}$

A framework to help explain the phenomena of a theory's acceptance is historian of science Thomas Kuhn's Structure of Scientific Revolutions. Kuhn posits that a scientific revolution is a noncumulative developmental episode in which an incompatible new paradigm replaces, in whole or in part, an older paradigm. ${ }^{24}$ Kuhn explained that the shift in understanding that occurs during a scientific revolution is not a small one. Rather, the old and the new paradigms are fundamentally incompatible and the differences cannot be reconciled. The acceptance of the new paradigm often requires a redefinition of the corresponding science, a complete rewrite of the science's textbook. However, the textbook will only change if the scientific community of interest accepts the new paradigm as valid because undoubtedly the new

\footnotetext{
${ }^{22}$ Reynolds, Primer for Theory Construction, 106.

${ }^{23}$ Reynolds, Primer for Theory Construction, 11.

${ }^{24}$ Thomas S. Kuhn, The Structure of Scientific Revolutions. 3rd ed. (Chicago, IL: The University of Chicago Press, 1996), 10. Kuhn defines paradigms as scientific achievements that, for a time, a particularly scientific community acknowledges as supplying the foundation for its practice. Hereafter cited as Structure of Scientific Revolutions.
} 
paradigm affects the group that practices the field. Kuhn pointed out "the decision to reject one paradigm is always simultaneously the decision to accept another, and the judgment leading to that decision involves the comparison of both paradigms with nature and with each other."25

In the case of a military professional, if the fundamental ideas and concepts of warfighting change, then a complete rewrite of the warfare doctrine would be necessary. However for the doctrine to be rewritten, military professionals must accept the new theory, the new paradigm. If influential individuals do not recognize the need for change then the new theory will not take root. Huba Wass de Czege, tactics instructor at CGSC, founder and first director of the School for Advanced Military Studies (SAMS), pointed out "knowing why, when and how to change is key to maintaining an Army's effectiveness." ${ }^{26}$ Historically for the U.S. Army the "why, when, and how" to change is driven by society, recent experiences, changing budgets, and the nation's strategic ends. The practitioners, the military professionals, must accept or reject the evolution and proofs of the art and science of warfare for change to take effect. The parallels drawn between the process of doctrine development and Kuhn's concept of scientific revolutions are useful in that they help to highlight the utility for using Reynolds' definition of theory in attempting to ascertain the existence of a theory of warfare in the U.S. Army operations doctrine.

If an overarching theory does exist in the U.S. Army operations doctrine then it becomes important for the argument in this monograph to test the theory's utility. Three questions derived from Richard Swain's article "Filling the Void: the Operational Art and the U.S. Army," can serve as the evaluation criteria for the utility of each theory. The first question is does the theory form a system designed to achieve a purpose? Second, is the theory effective for interpreting events and guiding action? Finally, does the theory help connect tactical actions with strategic

\footnotetext{
${ }^{25}$ Kuhn, Structure of Scientific Revolutions, 92, 103, 18, and 77.

${ }^{26}$ Huba Wass de Czege, "How to Change an Army,” Military Review 77 (Jan/Feb 1997), 162.
} 
purposes $?^{27}$ Before arriving on whether or not the Army's operations doctrine has an underlying theory of warfare derived from history a review of the literature indicates that past theorists do influence how doctrine is developed. In the following section we examine from the literature the extent to which theory has been used to inform and influence doctrine development.

\section{Theorists and Warfare Theory}

In their 2011 Military Review article "Military Theory, Strategy, and Praxis" Jacob W. Kipp, a retired federal civil servant and adjunct professor at the University of Kansas, and Lieutenant Colonel Retired Lester W. Grau, a senior analyst for the Foreign Military Studies Office at Fort Leavenworth, pointed out that "theorists of old still hold sway" and that military professionals need to know the foundations of their profession. Kipp and Grau noted the continued influence and applicability of Clausewitz, Jomini, du Picq, Douhet, J.F.C. Fuller, Hart, Machiavelli, Mahan, Upton, Svechin, Triandafilov, and Tuchachevsky on the military profession. Further Kipp and Grau articulated the importance of studying these and other war theorists to acquire knowledge on operational art and science. In acquiring the knowledge imparted by war theorists, military professionals would gain an understanding of the foundations of their profession. Kipp and Grau pointed out that understanding was especially important in the postmodern world where the state no longer defined the nature of the conflict given the emergence of non-state actors. ${ }^{28}$

Kipp and Grau did not articulate anything new except for those military professionals who have not read the "theorists of old." In the 18th Century Marshal de Saxe in My Reveries on the Art of War, also articulated that the military professional needed to be well versed in both the

\footnotetext{
${ }^{27}$ Swain, "Filling the Void," 147.

${ }^{28}$ Jacob Kipp and Lester Grau, "Military Theory, Strategy, and Praxis," Military Review 91, no. 2 (Mar/Apr 2011), 12. According to Kipp the emergence of non-state actors operating across and within the boundaries of multiple states changes the nature of conflict.
} 
details and the sublime parts of warfare. ${ }^{29}$ For de Saxe the details entailed everything from recruitment, dress, equipment, training, tactics and logistics while the sublime referenced the understanding of all forms of warfare through the genius of the generals. ${ }^{30}$ The salient point in de Saxe's argument was that leaders needed to understand the reasons for both the details and the highest levels of warfare. The only way to gain the understanding of the details and the sublime was through the study of military history and past victorious generals. Victorious generals were those generals that exemplified genius and demonstrated a keen grasp of the sublime. For de Saxe it was just as important, if not more important, to understand the reasons, the theories, behind actions taken as it was to understand the actions themselves.

Clausewitz wrote, "The primary purpose of any theory is to clarify concepts and ideas that have become, as it were, confused and entangled." He went on to explain that not until the terms and concepts were defined could there be consensus, let alone a conversation, about the topic of interest. In other words, for Clausewitz, theory served to provide the common language to allow the discourse to take place. Clausewitz stated all theories must adhere to categories of phenomena and not account for unique cases. Talented, educated, military professionals can deal with unique cases. Theory should educate and guide the military professional in personal development, not to accompany him to the battlefield. Theory does not resist humans' natural

\footnotetext{
${ }^{29}$ Robert Audi, ed., The Cambridge Dictionary of Philosophy (New York: Cambridge University Press, 1995), 774. Here sublime is defined as a feeling brought about by objects that are infinitely large or vast or overwhelmingly powerful. In the Kantian view, the feeling of the sublime gives rise to awareness that men have powers of reason that are not dependent on sensation, but that legislate over sense. The sublime thus displays both the limitations of the sense of experience and the power of the mind. This power of the mind in terms of how de Saxe may have used it referred to that which defines a general's genius, his higher capacity for thought in the overwhelming experience of war. In French "le sublimé" or the sublime refers to that which is of the highest moral, intellectual, or aesthetic quality. Definition found in the online French dictionary at http://dictionary.reverso.net/french-definition/sublime (accessed on February 1, 2013) and translated using Google Translator.

${ }^{30}$ Saxe, Maurice de. My Reveries Upon the Art of War, in The Roots of Strategy, Book I ed. Thomas R. Phillip, (Mechanicsburg, PA: Stackpole Books, 1985), 189.
} 
tendency to want to organize ideas into rules and principles that if accepted as dogmas become dangerous. However, such rules and principles do and can provide a frame of reference instead of a guide to explicit action. War principles are not absolute binding frameworks for action rather they are representations of general forms, short cuts that can substitute individual decisions. ${ }^{31}$

Lieutenant Colonel Richard D. Hooker, dean of the NATO Defense College, in his 2000 Military Review article "Land Warfare: 21st Century Theory and Doctrine" stated that doctrine is a thought process for problem solving in war and the basis of doctrine should be a sound theory. ${ }^{32}$ According to Hooker, the fundamental relationship between theory and doctrine is that theory provides a mental picture of the battlefield and helps to explain interactions on the battlefield. Like Swain, Hooker espoused that theory comprises the ideas and concepts of warfare incorporated into the Army's doctrine. Hooker explained that without theory, doctrine would be little more than a collection of random principles and truisms. Doctrine becomes the link between theory and practice. ${ }^{33}$ Like Clausewitz, Kipp, and Grau, according to Hooker theory is not used to predict but helps decision makers by providing coherent explanations for understanding what is happening on the ground and guide decisions for what may need to happen.

Hooker highlighted the two prominent theories of warfare in Army doctrine. The two theories are attrition (or firepower-attrition) warfare theory and maneuver warfare theory respectively from Hans Delbruck's military strategies of annihilation and exhaustion. ${ }^{34}$ According

\footnotetext{
${ }^{31}$ Clausewitz, On War, 132, 139, 141, and 153.

${ }^{32}$ Richard D. Hooker, "Land Warfare: 21 st Century Theory and Doctrine," Military Review 80, no. 2 (Mar/Apr 2000), 85. Hereafter cited as "21 st Century Theory." Dr. Hooker is also author of Maneuver Warfare: An Anthology, By Their Deeds Alone: America's Combat Commanders on the Art of War, Wrath of Achilles: Essays on Command in Battle and more than thirty articles.

${ }^{33}$ Hooker, "21st Century Theory," 85.

${ }^{34}$ Hans Delbrück, History of the Art of War, Volume IV: The Dawn of Modern Warfare (Lincoln, Neb.: University of Nebraska Press, 1990), 442.
} 
to Delbruck, "The objective that the strategy of annihilation envisages is always the enemy army; it must be sought out and defeated." The objective of the strategy of exhaustion was to wear the enemy out "by blows and destruction of all kinds to the extent that in the end he prefers to accept the conditions of the victor, which in this case must always show moderation." 35

Firepower-attrition warfare focuses on the destruction of the enemy and is resource intensive in both manpower and equipment. In contrast, maneuver warfare does not require the annihilation of the enemy but rather seeks a position of relative advantage to achieve the desired policy aims. Consequently, in a resource constrained environment with a small professional force, maneuver warfare may be advantageous. The latter conclusion potentially provides some basis of the influence of maneuver warfare theory in U.S. Army operations doctrine today. ${ }^{36}$

In his 1984 Military Review article "How to Change an Army," Wass de Czege articulated that theory is the foundation of any science, warfare not being the exception. ${ }^{37}$ If Wass de Czege was correct and, in the case of the U.S. Army operations doctrine, the textbook of the art and science of warfare is FM 100-5 (predecessor to the present day Army Doctrine

\footnotetext{
${ }^{35}$ Gordon A. Craig, "Delbrück: The military Historian," in Makers of Modern Strategy: from Machiavelli to the Nuclear Age, eds. Peter Paret, Gordon A. Craig, and Felix Gilbert, (Princeton, N.J.: Princeton University Press, 1986), 341-343.

${ }^{36}$ Bruce Stanley, interviewed by author, Fort Leavenworth, KS, February 4, 2013. Discussions from the interview with Dr. Stanley provided the impetus for this notion. Dr. Schifferle recommended an interview with Dr. Stanley to garner additional perspectives on the relationship of history, theory and doctrine development. Dr. Stanley was contacted via email on January 30, 2013. The discussion during the interview focused on potential sources to elucidate the history, theory, and doctrine relationship. Sources discussed included the individuals and organizations involved in operations doctrine development, the strategic context and environment, and practice. Dr. Stanley conducted the interview with full understanding that his views and comments would be directly attributed to him.

${ }^{37}$ Huba Wass de Czege, "How to Change an Army," Military Review 77 (Jan/Feb 1997), 168. The original article was published in 1984. In 1997 Military Review republished the article due to its applicability to the changes the Army was undertaking as an organization. Another factor that provided impetus for the republishing of the article was a criticism of the 1993 FM 100-5 as having taken a step backward in the evolution of a sound theoretical basis for the future.
} 
Publication 3-0 Unified Land Operations (ADP 3-0)) then the Army's theoretical basis for warfare should be in the FM 100-5 and the ADP 3-0. In the following section we explore and analyze the U.S. Army's operations doctrine from 1976 to 1986 to elucidate what, if it existed, was the relationship between history, theory, and doctrine.

\section{DOCTRINE DEVELOPMENT POST VIETNAM TO 1986}

Doctrine is the crystallization of history and theory.

- Dr. Jeffrey Kubiak, SAMS Faculty $2013^{38}$

In 1973 the Army was emerging from one of its most traumatic periods tainted by the Tet

offensive of 1968, the 1971 investigation of the My Lai incident, the withdrawal from Vietnam and the shift in 1973 to an all-volunteer force. The U.S. Army was at a crossroads wanting to divorce itself from its experiences in Vietnam and reestablish its sense of professional identity. ${ }^{39}$ Although the Army leadership had determined they needed to prepare for two potential types of war, mechanized war in Central Europe and a light infantry war elsewhere, they made a conscious decision to focus on mechanized conventional war. ${ }^{40}$ After 1973, the U.S. Army began to refocus its efforts on Central Europe and the Soviet Union in light of its Vietnam experience and observation of the 1973 Arab-Israeli War. Coming out of Vietnam the U.S. Army believed it

\footnotetext{
${ }^{38}$ Jeffrey Kubiak, interviewed by author, Fort Leavenworth, KS, January 31, 2013. Discussions from the SAMS course, Design and Operational Art, on where doctrine comes from and Dr. Kubiak's repeated assertion that doctrine was the crystallization of history and theory provided the impetus for the interview. Dr. Kubiak was contacted in person on January 28, 2013, for a more in depth discussion as it related to this research. The discussion during the interview focused on ascertaining where the notion of a relationship between history, theory, and doctrine may come from as well as exploration of other views on the purpose of doctrine to elucidate why operations doctrine may not have an overarching theory. Dr. Kubiak conducted the interview with full understanding that his views and comments would be directly attributed to him.

${ }^{39}$ Jeffrey S. Wilson, “Transformational Leadership: William DePuy's Vision for the Army," Military Review140, no 5 (Sep-Oct 2011), 70.

${ }^{40}$ Robert A. Doughty, "The Evolution of U.S. Army Tactical Doctrine, 1946-1976." Leavenworth Papers 1 (Fort Leavenworth, KS: August 1979), 40. Hereafter cited as "Army Tactical Doctrine, 1946-1976."
} 
needed to improve its tarnished image and restructure the Army. ${ }^{41}$ Part of the restructuring included rewriting the operations doctrine; in a sense, the Army underwent a Kuhnian paradigm shift.

Swain argued that Army doctrine from the 1970s to the 1980s resulted from the negotiation of a series of small decisions and debates. ${ }^{42}$ The decisions and debates about the U.S. Army operations doctrine post-Vietnam remained amongst a small circle of influential individuals. The prominent figures in doctrine development throughout the 1970s and the 1980s included the Training and Doctrine Command (TRADOC) commander, his trusted agents and the Chief of Staff of the Army. Although Swain's narrative for examining doctrine development from the 1970s and 1980s focused on the role individual officers played, those individuals' ideas (their theories), experiences (personal histories), and education (study of history and warfare theorists) were crystallized in the doctrine.

Swain examined the roles General William M. DePuy, the Army’s first TRADOC Commander from 1973 to 1977, General Donn A. Starry TRADOC Commander from 1977 to 1981, and then Lieutenant Colonel Huba Wass de Czege played in transforming the idea of operational art in the U.S. Army into doctrine. Swain highlighted how each individual's experiences contributed to his ideas of what the Army doctrine should comprise, Swain stated "as always individual men mattered, men both of ideas and of authority." ${ }^{, 43}$ Swain also demonstrated that each officer involved tended to be well versed in history and classical war theorists. Swain pointed out General Starry was widely read and was responsible for the incorporation of history

\footnotetext{
${ }^{41}$ Doughty, “Army Tactical Doctrine, 1946-1976," 40. Also from Walter E. Kretchik, U.S. Army Doctrine: From the American Revolution to the War on Terror (Lawrence: University Press of Kansas, 2011), 193.

${ }^{42}$ Swain, "Filling the Void," 166.

${ }^{43}$ Swain, "Filling the Void," 147.
} 
in the CGSC curriculum. Swain noted the influence of classical and modern maneuver theorists on Lieutenant Colonel Wass de Czege contributed to conceptually broadening Army doctrine rendering it both interpretive and conceptual. ${ }^{44}$

There was little evidence that any of the military officers Swain wrote about developed their individual theory of war and or wrote doctrine that exemplified a personal theory. The ideas that DePuy, Starry, and Wass de Czege developed and manifested in their corresponding editions of FM 100-5 emerged from various sources. The sources of influence included their personal and professional experiences, their professional education, and their understanding of their contemporary environment. ${ }^{45}$ Hypothetically, had other men been in their place, the Army’s operations doctrine would have reflected different ideas about how the Army should conduct and prepare for war. DePuy and Starry could directly influence Army doctrine development as the respective TRADOC commanders charged with drafting and publishing the Army's doctrine in 1973 and 1980. The ideas that DePuy and Starry developed because of their personal and professional experiences were crystalized into doctrine. These men's experiences included the study of military history and theorists. Analyses of the three versions of FM 100-5 from 1976 to 1986 will illustrate the influence of military history, military theorists and their theories, as well as individuals' experiences had on doctrine development.

${ }^{44}$ Swain, "Filling the Void," 158.

${ }^{45}$ Swain, "Filling the Void," 149-151, 153 and 158. There was little evidence to ascertain that DePuy, Starry or Wass de Czege had developed an overarching theory of warfare that manifested itself in FM 100-5. DePuy's ideas about warfare were primarily derived from his experience in World War II and observations of the 1973 Arab-Israeli War. Similarly, Starry's ideas were derived from his experience in Europe the U.S. Army V Corps commander and his understanding that the Soviets too had changed their doctrine making some of the lessons from World War II irrelevant. Wass de Czege derived his ideas from his experience as well as his study of military history. 
$\underline{\text { FM 100-5 } 1976}$

The 1976 FM 100-5 was primarily a threat-based doctrine criticized for its generally prescriptive nature aimed at defeating Soviet forces in Central Europe. The 1976 edition of FM 100-5 focus on high intensity conflict in Central Europe in part reflected sentiments after Vietnam. ${ }^{46}$ The U.S. Army realized its ability to repel threats anywhere in the globe was limited and therefore the Army should focus on the most dangerous threat, the Soviet Union and the Warsaw Pact. ${ }^{47}$ This realization and the 1973 Arab-Israeli War influenced the emphasis on mechanized warfare and Soviet weapons systems capabilities in the 1976 FM 100-5.

In the summer of 1973, General DePuy was focusing on organizing TRADOC and rewriting the Army's doctrine was not a top priority. However, the 1973 Arab-Israeli War changed DePuy's priority, as articulated in the following passage.

Had no event as dramatic as the Arab-Israeli War of October 1973 happened to accelerate the process of updating doctrine, DePuy's initiatives in training and combat developments would have eventually led to an examination and updating of the Army's doctrine anyway. As it was, that war burst on the consciousness of Army planners and captured their attention as quickly as it did world headlines. The war was the catalyst that brought DePuy's training and combat developments initiatives to reaction as new doctrine. ${ }^{48}$

As Lieutenant Colonel Jeffrey Wilson, assistant professor of philosophy at the U.S. Military Academy pointed out in his 2011 Military Review article, the Israeli Defense Force used American equipment to defeat a much larger Syrian force equipped with Soviet made armor and using Soviet-style tactics. DePuy observed how effectively the Israelis coordinated the army and the air force to defeat the first wave of Syrian armor forces while disrupting the second and third

\footnotetext{
${ }^{46}$ Paul H. Herbert, "Deciding What Has to be Done: General William DePuy and the 1976 Edition of FM 100-5, Operations" (Fort Leavenworth, KS: Combat Studies Institute, 1988), 9. Hereafter cited as "DePuy and 1976 Edition."

${ }^{47}$ Herbert, "DePuy and 1976 Edition,” 5. Also from Doughty, “Army Tactical Doctrine, 1946-1976,” 40.

${ }^{48}$ Herbert, "DePuy and 1976 Edition,” 29.
} 
echelons of the larger Syrian forces. The lessons DePuy drew from his observations contributed to the refinement and reframing of how the Army would prepare to fight the next war. DePuy's experience as battalion commander in Europe during World War II also influenced him to adopt German tactical methods. One of DePuy's core beliefs was that leaders led by example and soldiers executed exactly what they were told. ${ }^{49}$ This idea would resonate in the development of the 1976 FM 100-5 through a generally prescriptive approach to warfare in Central Europe.

The concepts in the 1976 FM 100-5 set the foundation for instruction in the service schools, guided training and combat developments throughout the Army and presented the underlying principles for the Army's mission accomplishment. ${ }^{50}$ The fact that $F M 100-5$ set the foundation was not a new concept in 1976 and it persists today. What was different in the then new FM 100-5 was the stated purpose for military operations. In the 1976 edition, the purpose of military operations was to "destroy enemy military forces, and secure and defend important geographic objectives." ${ }^{, 51}$ The reality on the ground in Central Europe with limited forces at the commencement of hostilities, when and if war broke out required such a purpose. The purpose of the 1976 FM 100-5 exemplified Delbruck's annihilation theory, the destruction of the enemy forces.

The destruction of enemy forces and the securing and defending of geographic objectives is precisely a tenet of firepower-attrition theory according to descriptions given by both Swift, and Hooker which corresponds to Delbruck's annihilation theory. In firepower-attrition theory, the focus is on inflicting as many casualties as possible on the enemy forces in order to gain

\footnotetext{
${ }^{49}$ Walter E. Kretchik, U.S. Army Doctrine: From the American Revolution to the War on Terror (Lawrence: University Press of Kansas, 2011), 194. Hereafter cited as U.S. Army Doctrine.

${ }^{50}$ U.S. Department of the Army, Field Manual 100-5, Change 1, Operations (Washington D.C.: U.S. Government, July 1, 1976), i. Hereafter 1976 FM 100-5, Change 1.

${ }^{51}$ U.S. Department of the Army, 1976 FM 100-5, Change 1, 1-2.
} 
relative strength. The 1976 FM 100-5 doctrine writers understood that allied forces would be outnumbered therefore NATO and U.S. Army forces in Central Europe had to destroy the Soviet first echelon and attrite follow on forces. Firepower-attrition warfare allowed the U.S. Army in Central Europe to trade space for time as they awaited additional U.S. forces' arrival. ${ }^{52}$

The nature of war theory that influenced the 1976 edition of FM 100-5, tended to be prescriptive with tables and charts illustrating weapons capabilities and checklists for commanders. DePuy and the contributing authors of the 1976 FM 100-5 seemed to take for granted that the enemy was not a learning adaptive entity. ${ }^{53}$ The charts and checklists were specifically oriented toward ensuring almost rote memorization of Soviet capabilities as well as achieving a firm grasp of the terrain in Central Europe. The 1976 edition did not emphasize the human aspects of warfare. Rather 1976 FM 100-5 was more of a "by the numbers" how to execute war of attrition against the Warsaw Pact in Europe. The U.S. Army would have to rely heavily on modern technology and the lethality of new weapon systems. According to Walter Kretchik when writing about the 1976 FM 100-5 "Technology and men combined to form a weapon system, the blending of armor, a main gun, fire control, automotives, communications, and a crew capable of effectively employing it." ${ }^{54}$ Unlike the current definition of doctrine, which calls for fundamental principles that guide military forces' actions in support of national objectives, the 1976 FM 100-5 was less a guide to action and more a detailed prescription on how to fight the Soviets.

The third chapter of the 1976 FM 100-5 was dedicated to instruct Army leaders "How to fight," which was also the chapter's title. Chapter Three prescribed that corps and division

\footnotetext{
${ }^{52}$ Kretchik, U.S. Army Doctrine, 197.

${ }^{53}$ Kretchik, U.S. Army Doctrine, 201.

${ }^{54}$ Kretchik, U.S. Army Doctrine, 198.
} 
commanders were responsible for concentrating forces, brigade and battalion commanders controlled and directed the battle, and company commanders fought the battles. If there were any question of how exactly leaders would accomplish their tasks, checklists were provided to guide their actions. ${ }^{55}$ One such checklist in Chapter Three provided prerequisites to win a battle and emphasized meeting them to accomplish the mission successfully. First, combat power must be generated such that the combination of adequate forces and weapons are concentrated at the critical times and places. Second, the battle must be controlled and directed so that the maximum effect of fire and maneuver is concentrated at decisive locations. Third, the battle must be fought using cover, concealment, suppression, and combined arms teamwork to maximize the effectiveness of our weapons and to minimize the effectiveness of enemy weapons. Lastly, train teams and crews to use the maximum capabilities of their weapons. Other checklists found in the third chapter included outlining what field artillery provides, and what commanders should expect from combat service support operations. ${ }^{56}$

In similar fashion chapters four (offense), five (defense), and six (retrograde operations) lists outlined how or when to conduct each mission type. Subsequently later in each chapter, lists detailed what each element of the combined arms team could accomplish for each type of mission. Specifically in Chapter Six on retrograde operations, the chapter opened with two lists. The first listed why retrograde operations would be undertaken: to trade space for time; to disengage from enemy contact; and to move away from an area without enemy pressure. The second bulleted list outlined four instances when to conduct retrograde operations. ${ }^{57}$ Such lists that described the "how to" throughout the 1976 FM 100-5 had utility at the tactical level by

\footnotetext{
${ }^{55}$ U.S. Department of the Army, 1976 FM 100-5, Change 1, 3-1.

${ }^{56}$ U.S. Department of the Army, 1976 FM 100-5, Change 1, 3-1 and 3-3.

${ }^{57}$ U.S. Department of the Army, 1976 FM 100-5, Change 1, 6-1.
} 
providing a road map toward accomplishing diverse mission types. The prescriptive lists, useful for tactical level actions against the Soviet threat, reinforced the notion that the Army's operations doctrine focused too tactically. ${ }^{58}$ The narrow focus on the Soviet and Warsaw Pact threat in Central Europe was a reflection of the realities of the global context of the 1970s. To adapt to other threats a less prescriptive doctrine would be necessary.

The nature of the threat in the 1970s influenced Army doctrine development. Although there were references stating the Army had to be ready to face any adversary, the 1976 FM 100-5 was primarily concerned with the Soviet and Warsaw Pact threat. ${ }^{59}$ The nature of that war would be a mechanized high-intensity conflict. From observations of the 1973 Arab-Israeli War, General DePuy concluded that the lethality of weapons continued to increase and high loses could be expected in short periods particularly in the first battle. DePuy understood it would take time to mobilize additional forces to support efforts in Central Europe if hostilities broke out. The allies would be outnumbered and could expect the battlefield to include the use of nuclear weapons. To assure NATO and U.S. forces' success, the units present in Germany would have to fight attrition warfare and trade space for time until reinforcements could arrive. The presence of firepowerattrition warfare theory evolved from lessons learned during World War II. The 1976 FM 100-5 was a product of the lessons learned during past conflicts, couched as types of military theories derived from personal and collective experiences, and the realities forces faced in Central Europe.

The 1976 FM 100-5 did not explicitly have an overarching theory of warfare influenced by military history, military theorists and their theories. However, it was evident that the U.S. Army's experience in Vietnam, observation of the 1973 Arab-Israeli War, and General DePuy's professional experience in Europe in World War II all influenced the development of the 1976

\footnotetext{
${ }^{58}$ Swain, "Filling the Void," 153.

${ }^{59}$ U.S. Department of the Army, 1976 FM 100-5, Change 1, 3-1.
} 
FM 100-5. The 1976 operations doctrine was comprised of a collection of ideas and concepts formed from all these influences. To paraphrase Swain, these ideas became the unified theories of warfighting for the Army in 1976. The Soviets and Warsaw Pact threat were ultimately the driving force for the 1976 FM 100-5. Although firepower-attrition warfare theory was prominent in the 1976 edition of FM 100-5, the need for firepower-attrition theory emerged from the realities the forces faced in Central Europe not from the theory.

\section{FM 100-5 1982}

Like the 1976 edition of FM 100-5, the 1982 edition was not a direct product of history and theory. The 1982 FM 100-5 was a threat-based doctrine that opened the aperture on the nature of potential future conflict. Explicitly the 1982 edition authors acknowledged and addressed threats beyond the Soviets and Warsaw Pact as well as recognized the need for adaptive leadership.

In addressing threats beyond the Soviets in Central Europe, the authors of the 1982 FM 100-5 heeded Clausewitz's warning about necessity for war theory to not only focus on the mechanics (the physical aspects) of war but also take into account the psychological, the human, aspects involved. ${ }^{60}$ As in the 1976 edition in the 1982 FM 100-5 key individuals played a role in the development of the Army's operations doctrine. In their 1982 Military Review article "The New FM 100-5", then Lieutenant Colonel Wass de Czege and Lieutenant Colonel L.D. Holder, both authors of the 1982 FM 100-5, pointed out that the 1976 edition had discounted the effects of maneuver and other intangible factors which had historically decided battles. ${ }^{61}$ Other shortcomings identified by General Starry (TRADOC Commander), Lieutenant General Richard

\footnotetext{
${ }^{60}$ Clausewitz, On War, 75 and 137. As Clausewitz pointed out, at the end of the day war is a human endeavor of the struggle to impose ones will on the adversary.

${ }^{61}$ Huba Wass de Czege and L.D. Holder, “The New FM 100-5,” Military Review 62 (July 1982), 54.
} 
Cavazos (III Corps commander) and others in positions to influence FM 100-5 development, included an updated assessment of the threat, soldiers' psychological preparation for war, and how to best prepare officers to succeed in any battle. ${ }^{62}$

Starry deduced after commanding in Europe that the 1976 Active Defense doctrine did not account for the Soviet's new tactics. Cavazos believed soldiers' psychological preparation for combat should be in doctrine. With Starry as the TRADOC commander, the 1982 FM 100-5 placed more emphasis on the human aspect of war as Army leadership endeavored to show the importance of leadership and the morale of the force. To Starry's points Wass de Czege and Holder believed the approach in the 1976 FM 100-5 "played down the human dimension of combat" and the emphasis on the defensive nature of the first battle "discouraged serious consideration of the attack. ${ }^{, 63}$ Consequently, the doctrine shifted from a defensive war of attrition theory type to the more flexible and mobile maneuver warfare theory type doctrine.

The 1982 edition of FM 100-5 also shifted to describe warfare in general rather than the specific circumstances in Central Europe. Unlike the 1976 edition, there was no section providing a list of the "how to fight," rather the 1982 edition was divided into four parts. The first part provided a description of the Army, the Airland Battle concept, the diverse potential battlefield environments, modern logistics and intelligence operations, and the overall conduct of operations in a non-linear environment. The second part focused on offensive operations. The third part focused on defensive operations. The fourth part focused on joint, contingency, and combined operations. $^{64}$

\footnotetext{
${ }^{62}$ Kretchik, U.S. Army Doctrine, 202.

${ }^{63}$ Huba Wass de Czege and L.D. Holder, “The New FM 100-5,” Military Review 62 (July 1982), 54.

${ }^{64}$ U.S. Department of the Army, Field Manual 100-5, Operations (Washington D.C.: U.S. Government, August 22, 1982), ii and 7-1. Hereafter cited as 1982 Field Manual 100-5.
} 
The 1982 FM 100-5 made explicit its theoretical ideas about warfare. Wass de Czege and Holder asserted that they drew the theoretical content of the 1982 FM 100-5 "from the lessons of history, the writings of the great military theorists and the Army's historic approach to operations." ${ }^{, 65}$ As a demonstration of Wass de Czege and Holder's assertion, Chapter Two focused on the theoretical fundamentals for combat operations. In the Chapter Two introduction, the 1982 FM 100-5 authors noted the principles of war as the foundation of the U.S. Army's operations. While an in-depth discussion of the newly reintroduced principles of war was deferred to Appendix B, Chapter Two introduced Airland Battle as the Army's operational concept with four basic tenets. The tenets were initiative, depth, agility, and synchronization. Initiative meant that in every case the U.S. Army should maintain the offensive spirit, make decisions and act quicker than the enemy to seize and retain the advantage. Depth referred to time, distance, and resources in terms of ensuring momentum in the attack and elasticity in the defense. Agility denoted to the organizations flexibility for action derived from "quick minded, flexible leaders" who could act faster than the adversary could to avoid enemy strengths and attack vulnerabilities. Synchronization meant to demonstrate the necessity to ensuring coordinated action and unity of effort throughout the force. ${ }^{66}$

The authors also introduced the new concept of the three levels of war in Chapter Two. The importance of the three levels of war resided in making the connection between war and politics. The strategic level referred in the abstract to the collective armed forces' employment to achieve political objectives. The operational level was described as the "theory or larger unit operations" as well as involving the planning and conducting of campaigns to meet strategic

\footnotetext{
${ }^{65}$ Huba Wass de Czege and L.D. Holder, “The New FM 100-5," Military Review 62 (July 1982), 55.

${ }^{66}$ U.S. Department of the Army, 1982 Field Manual 100-5, $2-2$.
} 
objectives. The tactical level referred to smaller unit techniques to "win battles and engagements" in support of operational level objectives. ${ }^{67}$

The new emphasis on the morale of the force was important in the continued shaping of the all-volunteer force and the type of war they expected fight. As a part of the human dimension, the 1982 FM 100-5 reintroduced principles of war to address the sentiment that officers needed to be better prepared to succeed in any battle. ${ }^{68}$ Additionally, while emphasizing the human dimension of warfare the 1982 FM 100-5 used historical examples, more than the previous edition, to illustrate key points. With regard to the morale of the force, the authors of the 1982 FM 100-5 emphasized the importance of good leadership and soldiers' morale.

The conditions of combat on the next battlefield will be less forgiving of mistakes and more demanding of leader skill, imagination, and flexibility than any in history. General S. L. A. Marshall's studies of the U.S. Army teach that American soldiers will fight resolutely when they know and respect their leaders and feel they are part of a good unit. $^{69}$

The 1982 FM 100-5 authors cited de Saxe to illustrate the point that "a soldier's courage must be reborn daily" and it is up to the leaders to ensure this happens. "Leaders create cohesion and maintain discipline. Soldiers who serve in disciplined, cohesive units will be on hand with functioning equipment when the decisive moment arrives." Continuing to emphasize the importance of leadership the authors pointed out that in order to gain greater understanding and become better leaders it is important to study great leaders of the past. ${ }^{70}$ Wass de Czege, Holder and Lieutenant Colonel Henriques, the third writer of the 1982 FM 100-5, drew lessons from du

\footnotetext{
${ }^{67}$ U.S. Department of the Army, 1982 Field Manual 100-5, 2-3.

${ }^{68}$ Kretchik, U.S. Army Doctrine, 202.

${ }^{69}$ U.S. Department of the Army, 1982 Field Manual 100-5, 1-3.

${ }^{70}$ U.S. Department of the Army, 1982 Field Manual 100-5, 2-10.
} 
Picq and British military historian John Keegan on the "moral dimension of combat, involving leadership, courage, endurance, and fear.",71

The third chapter, which focused primarily on terrain and military aspects of terrain, was rich with historical examples and references. In describing decisive terrain, control of Little Round Top at Gettysburg illustrated the point. While describing the use of unlikely routes to attack an enemy the authors noted, "The cliffs at Quebec, the tides of Inchon, and the Ardennes forest all appeared impassable to their defenders," however," enterprising commanders have won decisive victories by striking suddenly over unlikely routes." Other examples given to illustrate indirect approaches were Patton's use of the Norman roads of France and Israel's 1967 penetration of the Sinai along the trace of a Roman road. Similarly, to demonstrate the importance of reinforcing terrain the Kursk salient of 1943 was referenced to illustrate it was much more difficult to attack once the position was improved. ${ }^{72}$

Chapter Three was not the only section of the 1982 FM 100-5 that used historical examples to illustrate key points. Both chapters on defensive and the offensive operations opened up with two to three pages of the historical perspective for each. Chapter Eight on the fundamentals of offensive operations opened with "From Yorktown in the Revolutionary War to the Yalu River in the Korean War, the U.S. Army has a long history of successful offensive campaigns. Sherman, Jackson, MacArthur, Bradley, and Patton are names which stand out from a long list of American leaders who were expert in the attack."73 The remainder of the historical

${ }^{71}$ John L. Romjue, From Active Defense to Air Land Battle: the Development of Army Doctrine 1973-198 (Fort Monroe, VA: United States Army Training and Doctrine Command, 1984), 55.

${ }^{72}$ U.S. Department of the Army, 1982 Field Manual 100-5. Reference to Little Round Top is found on 3-1, indirect approach reference and examples are found on pages 3-5 and 3-6, and reference to the Kurks salient is found on page 3-7.

${ }^{73}$ U.S. Department of the Army, 1982 Field Manual 100-5, 8-1. 
opening of the chapter was a two-page discussion of General Grant's Vicksburg Campaign.

Similarly, Chapter Ten on the fundamentals of defensive operations opened with minor examples of defensive operations as illustrated below.

Gettysburg, for example, was an entirely reactive battle. The outcome depended on the attacker's errors, not on the defender's exploitation of them. At the Battle of Kursk in 1943, the defense was better balanced. Early counterattacks strengthened the reactive phase, and the entire defending army ultimately went on the offensive to exploit its gains.... A closer parallel to the fluid conditions, rapid maneuver, and calculated risks of future operations occurred in the Battle of Tannenberg. ${ }^{74}$

The discussion quickly expanded to give a more in depth account of the Battle of Tannenberg fought in East Prussia in August 1914. In both historical accounts of the Vicksburg Campaign and the Battle of Tannenberg, the 1982 FM 100-2 authors provided both a narrative and an illustration of the battle to ensure understanding.

From a theoretical standpoint as alluded to earlier the 1982 edition shifted from firepower-attrition theory to a maneuver theory of warfare. Additionally in stark contrast to the 1976 edition's emphasis on firepower and the first battle, which was defensive in nature, the 1982 FM 100-5 reestablished the offense as the decisive form of war. References to Clausewitz were found throughout as well as insights from Liddell Hart's Strategy: The Indirect Approach were incorporated so that commanders would encourage initiative in their subordinates. ${ }^{75}$ Additionally, the tactical concepts of the offense were drawn from Liddel Hart and J.F.C. Fuller in development of the sections on the offense throughout the 1982 edition of $F M 100-5 .^{76}$ Other theorists explicitly referenced in the 1982 FM 100-5 included du Picq, de Saxe, and Sun Tzu. ${ }^{77}$

${ }^{74}$ U.S. Department of the Army, 1982 Field Manual 100-5, 10-1 and 10-2.

${ }^{75}$ Kretchik, U.S. Army Doctrine, 206-207.

${ }^{76}$ John L. Romjue, From Active Defense to Air Land Battle: the Development of Army Doctrine 1973-198 (Fort Monroe, VA: United States Army Training and Doctrine Command, 1984), 56.

${ }^{77}$ U.S. Department of the Army, 1982 Field Manual 100-5, A-3. In the References section 
While providing general descriptions of the different types of operations under diverse conditions the 1982 FM 100-5 also ensured to address combined operations in Central Europe and in South Korea. Expanding the focus beyond Europe was an attempt to address, as Wass de Czege and Holder recognized that U.S. Army doctrine needed to "be adaptable to operations anywhere in the world."78 According to the authors of the 1982 FM 100-5, the "Airland Battle doctrine... was based on securing or retaining the initiative and exercising it aggressively to defeat the enemy" and the enemy would be attacked in depth through the synchronization of fire and maneuver. ${ }^{79}$ However, the types of conditions under which the Army could expect to operate in still tended to focus on conventional warfare and under the potential of nuclear conditions. More focus on contingency operations and low intensity conflict would not come until the next revision of FM 100-5 in 1986.

The 1982 FM 100-5 did not have an explicit overarching theory of warfare influenced by military history, military theorists and their theories. However, at least two of the authors, Wass de Czege and Holder, explicitly stated that to develop the 1982 FM 100-5 theoretical content, they drew from lessons from history and military theorists. ${ }^{80}$ The 1982 concept of Airland Battle was comprised of a collection of ideas and concepts informed and influenced by the TRADOC commander, General Starry, the writers, Wass de Czege, Holder, and Henriques, and other key leaders in positions such as then III Corps commander General Cavazos. The ideas that these men

of the 1982 FM 100-5 there is a bibliography which lists Ardant du Picq's Battle Studies: Ancient and Modern, Clausewitz's On War, Lidel Hart's Strategy: The Indirect Approach, de Saxe's Reveries on the Art of War, and Sun Tzu's The Art of War.

${ }^{78}$ Huba Wass de Czege and L.D. Holder, “The New FM 100-5," Military Review 62 (July 1982), 57.

${ }^{79}$ U.S. Department of the Army, 1982 Field Manual 100-5, 2-1.

${ }^{80}$ Huba Wass de Czege and L.D. Holder, “The New FM 100-5,” Military Review 62 (July 1982), 55. 
developed became the refined unified theories of warfighting for the Army in 1982 that evolved the concept of Active Defense to the Airland Battle concept. The Soviets and Warsaw Pact threat continued to constitute the primary focus for the Army with the recognition that the U.S. Army had to be prepared to fight anywhere in the world. Firepower-attrition warfare theory was no longer prominent in the 1982 edition of FM 100-5, rather the balance and synchronization with maneuver warfare theory emerged from the realities the forces faced in Central Europe would face. ${ }^{81}$ Once more reality and individual experiences, informed by the study of military history and theory, helped formulate doctrine not theory.

\section{FM 100-5 1986}

In the 1986 edition of FM 100-5 the authors sought to improve upon the concepts and ideas from the previous edition. The authors also aimed to clarify and address concerns expressed by outside influencing forces such as the NATO allies. The Army's operations doctrine was evolving from a "how to fight" the Soviets in Central Europe manual in 1976 to a "how to conduct military operations" in support of strategic objectives anywhere on the globe. In expanding the purpose of doctrine to the realities of international relations, the FM 100-5 provided insights, whether real or perceived, about U.S. intentions to external audiences. The authors of the 1986 FM 100-5 were keen on addressing both the needs of the Army and the allies' openly debated concerns over the offensive nature and tone of the doctrine. As in the 1976 and 1982 editions in the 1986 FM 100-5 key individuals played a role in the development of the Army's operations doctrine. Specifically involved were Wass de Czege, then director of SAMS, Holder, then an Army War College Fellow at SAMS, and Richardson, then TRADOC

\footnotetext{
${ }^{81}$ John L. Romjue, From Active Defense to Air Land Battle: the Development of Army Doctrine 1973-198 (Fort Monroe, VA: United States Army Training and Doctrine Command, 1984), 56. According to Romjue the maneuver was seen as the better way to interdict the enemy and then Combined Arms Center commander General Richardson gave the early directive in 1980 to restore the balance between firepower and maneuver into the 1982 FM 100-5.
} 
commander plus a new member to the authoring team, Richard Hart Sinnreich, then deputy director of SAMS. ${ }^{82}$

To insure the Army was prepared to support strategic objectives, whatever the range, the 1986 FM 100-5 tempered the prospects of a mechanized high intensity conflict in Central Europe with the prospects of non-mechanized low intensity conflict to a better extent than the 1982 FM 100-5. The 1986 FM 100-5 dedicated a chapter to discuss contingency operations and made a distinction between high intensity, mid intensity conflicts and low intensity conflict. ${ }^{83}$ Additionally, in comparison to the 1976 and 1982 FM 100-5 in the 1986 edition, the prospects of a nuclear war were reduced in part to appease the concerns that the previous FM 100-5 language was insensitive ${ }^{84}$ The 1986 FM 100-5 emphasized that the highest national levels would make any decisions to use nuclear weapons. The Army at this point would not engage in tactical nuclear operations unless directed to by the national authority. However, in the 1986 edition of FM 100-5 as part of assessing the threat the Army recognized that the Soviets possessed a nuclear capability and that the Soviets could potentially use nuclear weapons against the U.S. as demonstrated by the following.

Soviet doctrine emphasizes the principle of mass and seeks victory through relentless offensive operations. If nuclear and chemical weapons are required to ensure success, they will be used. Soviet planners recognize that the employment of nuclear or chemical weapons may alter tactics, force requirements, and rates of advance. However, they expect little -deviation from their basic doctrine, and equip, arm, and train their own forces and their allies to fight with nuclear and chemical weapons. Our own forces can therefore do no less. ${ }^{85}$

\footnotetext{
${ }^{82}$ Swain, "Filling the Void," 163.
}

${ }^{83}$ U.S. Department of the Army, Field Manual 100-5, Operations (Washington D.C.: U.S. Government, May 5, 1986), 2-5. Hereafter cited as 1986 Field Manual 100-5.

${ }^{84}$ William R. Richardson, "FM 100-5: The Airland Battle in 1986," Military Review 66 (Mar 1986), 9.

${ }^{85}$ U.S. Department of the Army, 1986 Field Manual 100-5, 85. 
In the 1986 FM 100-5, the purpose of military operations was different from the 1976 edition. The purpose was to impose our will on the enemy to accomplish the mission to meet political objectives. ${ }^{86}$ The focus on achievement of policy objectives further demonstrates the shift to maneuver warfare theory as well as articulation of Clausewitz axiom that war is an extension of policy by other means.$^{87}$ General William Richardson, TRADOC commander from 1983 to 1986 , stated that the 1986 FM 100-5 "described the operational level of war as the linchpin between strategy and tactics" and "clearly differentiated" between tactical and operational war fighting. Richardson further clarified that the notions on maneuver, anticipation and forward thinking in the 1986 edition did not reside in the operational level but had broad applicability like the principles of war. ${ }^{88}$

The 1986 FM 100-5 did not provide tables or how to checklists like the 1976 edition. The 1986 FM 100-5 was more descriptive focusing more on the operation level of war than on tactics. The 1986 FM 100-5 focused military professionals on what leaders ought to consider ensuring achievement of military objectives that met policy objectives. Underscored by a balanced theory of maneuver and firepower-attrition, the 1986 edition set out to "present a stable body of operational and tactical principles rooted in actual military experience and capable of providing a long-term foundation for the development of more transitory tactics, techniques and procedures." ${ }^{, 89}$ According to Richardson, the 1986 FM 100-5 was more theoretical by necessity to satisfy U.S. needs outside of Central Europe..$^{90}$

${ }^{86}$ U.S. Department of the Army, 1986 Field Manual 100-5, 9 and 14.

${ }^{87}$ Clausewitz, On War, 88 .

${ }^{88}$ William R. Richardson, "FM 100-5: The Airland Battle in 1986," Military Review 66 (Mar 1986), 5.

${ }^{89}$ U.S. Department of the Army, 1986 Field Manual 100-5, i.

${ }^{90}$ William R. Richardson, "FM 100-5: The Airland Battle in 1986," Military Review 66 
The 1986 edition explicitly introduced Clausewitz's concepts of friction, center of gravity and culminating point. The authors of the 1986 edition made it a point to state that these ideas were not new to Army doctrine. Rather, the authors pointed out that until recent time the ideas of friction, center of gravity, and culminating point were not articulated. ${ }^{91}$ The 1986 FM 100-5 introduced friction and defined it as "the accumulation of chance errors, unexpected difficulties, and the confusion battle that impedes both sides." ${ }^{92}$ Commanders needed to consider the presence of friction when formulating their plans because, as Clausewitz pointed out, friction is an intrinsic part of war. Similarly, from Jomini the authors of the 1986 FM 100-5 incorporated the concept of lines of operations throughout with an in depth discussion in an appendix.

The 1986 edition also addressed center of gravity and culminating point throughout but an additional page and one half and two pages respectively of an appendix entitled "Key Concepts of Operational Design" discussed each concept at length. This later notion of a separate appendix to discuss theoretical concepts further illustrates that theory and theoretical concepts played a more dominant role in the 1986 edition of FM 100-5. Unlike in the previous editions of FM 100-5, the authors explicitly stipulated in the preface that the 1986 FM 100-5 was "both more theoretical and more general so as to meet U.S. needs in other theaters [not solely focused on Central Europe]. ${ }^{, 93}$ The theoretical construct for the 1986 FM 100-5 also expanded the role of commanders and all leaders.

(Mar 1986), 8.

${ }^{91}$ U.S. Department of the Army, 1986 Field Manual 100-5, 179. Appendix B points out that the concepts of center of gravity, line of operations, and culminating point are not new concepts to Army application doctrine has not explicitly discussed them "for some time." In the 1976 FM 100-5, there were no references to or discussion of any of these concepts.

${ }^{92}$ U.S. Department of the Army, 1986 Field Manual 100-5, 23, 75, 109, and 110. The explicit definition of friction is on page 16.

${ }^{93}$ U.S. Department of the Army, 1986 Field Manual 100-5, i. The original was not in italics, here theoretical was italicized for emphasis. 
Like the 1982 edition, the 1986 FM 100-5 illustrated ideas of the human aspects in warfare similar to those found in Clausewitz, where he emphasized the role of the character of the commander. The 1986 FM 100-5 outlined three essential components for the Army's superior performance in combat operations, leadership, doctrine, and weapons. Leadership, an intangible key human aspect of war was first. According to the 1986 FM 100-5 what the Army depended on to meet the current threats and challenges "first and foremost [was on the] superb soldiers and leaders with character and determination who will win because they simply will not accept losing." 94 The character of the force primarily shaped by the technical and intellectual capabilities of the commander took center stage parallel to Clausewitz's principal moral elements. ${ }^{95}$ With respect to the unforgiving nature and lethality of weapons in future battlefields, the 1986 FM 1005 stated that leaders would have to exemplify great skill, imagination, and flexibility to attain the respect and loyalty of their subordinates. The 1986 FM 100-5 authors stated, "Wars are fought and won by men, not by machines. The human dimension of war will be decisive in the campaigns and battles of the future just as it has been in the past." 96 The new found emphasis on the human dimension of warfare began to point to an evolution from a purely threat based doctrine in 1976 to a more theoretical and descriptive doctrine in the 1986 FM 100-5.

The 1986 FM 100-5 also did not explicitly have an overarching theory of warfare influenced by military history, military theorists and their theories. Like the preceding 1982 FM 100-5 the 1986 edition was comprised of a collection of ideas and concepts formed from various influences. Most of the same key individuals who had contributed to the authorship and ideas in the 1982 FM 100-5 were involved in the production of the updated FM 100-5 in 1986. The 1986

${ }^{94}$ U.S. Department of the Army, 1986 Field Manual 100-5, 5.

${ }^{95}$ Clausewitz, On War, 186. Clausewitz's principal moral elements were the skill of the commander, the experience and courage of the troops, and their patriotic spirit.

${ }^{96}$ U.S. Department of the Army, 1986 Field Manual 100-5, 5. 
FM 100-5 reflected what its authors sought, "the lessons learned since that time [the release of the 1982 edition] from combat operations, teachings, exercises, wargames, and comments from the Army in the field." ${ }^{, 97}$ The differences between the 1982 and 1986 FM 100-5 were subtle. The Soviets and Warsaw Pact threat continued to constitute the most dangerous threat although the war in Central Europe was least likely conflict to erupt. The balance between firepower attrition and maneuver warfare remained as well as the emphasis of the need to synchronize all actions on the battlefield to meet strategic objectives. Once more reality and individual experiences helped formulate doctrine, however more than the previous editions the 1986 FM 100-5 development was informed by the study of military history and theory. However, the study of theory and history did not result in formulation of an overarching theory of war.

\section{Summary}

The three editions of FM 100-5 focused on what was the most dangerous threat, the Soviets and the Warsaw Pact, with each new edition incrementally acknowledging the need for a more global perspective. The differences between 1982 and 1986 editions of FM 100-5 were subtle while the differences between the 1976 and the 1982 editions were not. According to Wass de Czege, the major differences between the 1976 and 1982 manuals were theory, geographical orientation, approach to nuclear and chemical operations, accommodation of technical change, operations in depth, defensive operations and offensive doctrine. ${ }^{98}$ The 1982 and 1986 editions of FM 100-5 resulted from evolutionary adjustments made to the 1976 edition. For all three FM 100-5 editions the abstract statements included ideas about the nature of the threat, the desired purpose and the means available toward achieving the purpose. The evolution of the 1976 FM

\footnotetext{
${ }^{97}$ U.S. Department of the Army, 1986 Field Manual 100-5, i-ii.
}

${ }^{98}$ Huba Wass de Czege and L.D. Holder, "The New FM 100-5," Military Review 62 (July 1982), 55. Was de Czege and Holder comments on the 1982 revision of FM 100-5, which was very different from the 1976 edition. 
100-5 to the 1982 FM 100-5, which was further refined in 1986, was like Kuhn's scientific revolution, in which the incompatible new paradigm of Airland Battle in part replaced the older Active Defense paradigm. Once the concepts of Airland Battle were accepted, a rewrite of the Army's operations doctrine redefined how the Army would or should wage war in the future. In rewriting the Army's textbook, FM 100-5, the Army leadership explicitly demonstrated that they knew "why, when, and how" to change to insure the Army remained effective. During each revision of FM 100-5, there were key individuals who led the way influencing the content of the doctrine as well as ensuring the new doctrine's acceptance amongst the community of interest, the Army.

The 1976 FM 100-5 presented General DePuy's vision for the U.S. Army drawn from his personal experiences in Central Europe during World War II and from lessons learned from the 1973 Arab-Israeli war. Like DePuy before him, Starry was influential in the 1982 FM 100-5 rewrite. Starry played a prominent role in the evolution of the Army's Active Defense doctrine after he commanded in Central Europe and gained a better appreciation for the reality of U.S. Army operations in Central Europe. Starry learned the realities on the ground in Central Europe were different from what they had been for the U.S. during World War II and that the adversary too had adjusted his doctrine. Having had an intricate role in the development of the Airland Battle doctrine in 1982 FM 100-5, Richardson, as the TRADOC commander, sought to ensure the updated 1986 FM 100-5 refined key concepts and incorporated lessons learned since the last edition of the doctrine. The Starry, Richardson, Wass de Czege, Holder, Henriques, and Sinnreich all grasped that the study of military history, military theorists and their corresponding theories helps military professionals gain an understanding of the foundations of their profession. With the understanding of the foundations of their profession and their personal experiences, these key individuals moved to rewrite the Army's operations doctrine.

In rewriting the Army's operations doctrine, FM 100-5, the Army leadership explicitly demonstrated that they knew "why, when, and how" to change to insure the Army remained 
effective. The adjustments or evolutions to the 1976 FM 100-5 through 1986 rose from open debates amongst military professionals based on reality not an overarching theory of war. In contrast to the 1976 FM 100-5 being the capstone doctrine, which asserted the Army's primary objective as winning the land battle, both the 1982 and 1986 FM 100-5 became the Army's keystone how to fight manual and asserted the Army's fundamental mission was to deter war. ${ }^{99}$ The distinction in each one of the stated purposes in the three FM 100-5 editions illustrated the presence of the underlying theory of firepower-attrition or maneuver in each edition of the doctrine. ${ }^{100}$ To varying degrees, based on an assessment of the reality on the ground and within the strategic context, there was emphasis on Delbruck's annihilation and exhaustion theories.

In each edition of $F M 100-5$, there was a progression in the doctrine from firepowerattrition to a balanced approach that included maneuver theory. The destruction of enemy forces and the securing and defending of geographic objectives found in the 1976 edition depicted a tenet of firepower-attrition theory while the focus on achievement of policy objectives in the 1982 and 1986 editions articulated the mission objectives of maneuver theory that Swift and Hooker discussed. The idea of a balanced approach where both concepts of firepower-attrition theory and maneuver warfare theory came to fruition in an iterative process involving consideration of historical practices during World War II, the lessons learned during the 1973 Arab-Israeli War and the Soviet's new doctrine. History and reality came together to influence the authors' ideas and views for developing the Army's operations doctrine. As Sinnreich pointed out, theory

${ }^{99}$ U.S. Department of the Army, 1976 FM 100-5, Change 1, 1-3, 1982 Field Manual 1005, i and 1986 Field Manual 100-5, 1 respectively for each edition.

${ }^{100}$ Jeffrey W. Long, "The Evolution of U.S. Army Doctrine: From Active Defense to Airland Battle and Beyond" (Fort Leavenworth, KS: U.S. Army Command and General Staff College, 1991), 31. 
helped formulate questions of history and conversely history helped challenge the assertions of the theory. ${ }^{101}$

None of the three editions of FM 100-5 from 1976 to 1986 had an explicit overarching theory of war controlling its content. Each FM 100-5 analyzed comprised a collection of ideas about the nature of future conflict derived from history, past collective and individual experiences. The dynamic interactions amongst the diverse sources of influence gave rise to an iterative, organic process similar to Kuhn's paradigm shift, where new paradigms replaced old ones. Using Paul David Reynolds' definition of theory that refers to a "set of abstract statements that are considered part of a scientific body of knowledge...in the causal process form," the three editions of FM 100-5 adhered to this meaning. The abstract ideas on the threat, the offense, the defense, nuclear warfare, firepower-attrition, maneuver, and leadership were important to the conduct of warfare. Additionally, all the ideas about the threat, the offense, the defense, nuclear warfare, firepower-attrition, maneuver, and leadership were in the causal process form because they underscored the fundamental principles of warfare. The operations doctrine, using the $J P 1$ 02 definition of "fundamental principles by which the military forces guide their actions in support of national objectives," for 1976 was guided by the objective of destroying the enemy's forces while 1982 and 1986 doctrine was guided by the objective of deterrence. The operations doctrine, guided by fundamental principles to meet strategic objectives, attempted to describe ideas and concepts of how the Army should wage war in the future.

\section{WAS THE DOCTRINE PURPOSEFUL AND USEFUL?}

Doctrine is the reflection of how we, [the U.S. Army], think about future wars. Doctrine development is an organic process.

\footnotetext{
${ }^{101}$ Richard Hart Sinnreich, "Awkward Partners: Military History and American military Education," in The Past as Prologue: the Importance of History to the Military Profession, eds. Williamson Murray and Richard Hart Sinnreich (New York: Cambridge University Press, 2006), 63.
} 
- Dr. Mark Calhoun, SAMS Faculty $2013^{102}$

Although an overarching theory of warfare did not reside in each edition of FM 100-5 analyzed, each edition of the FM 100-5 from 1976 to 1986 was in varying degrees influenced by theory, usually a collection of theories. Following Swain's premise that these collections of ideas formed systems that became unified institutional theories of warfighting it is important for the argument in this monograph to determine the utility of the collective ideas. Was the influence of theory useful for how the Army envisioned and prepared for future warfare? The three questions derived from Swain's article "Filling the Void: the Operational Art and the U.S. Army" help ascertain the utility of each edition of FM 100-5 analyzed. The first question asks whether the theory forms a system designed to achieve purpose. The second question asks if the theory is effective for interpreting events and guiding action. The third question asks whether the theory helps connect tactical actions with strategic purposes. What follows, answers the three questions.

Answering the first question in the affirmative, the multiple theories in the 1976 edition did form a system to achieve a specific purpose of defeating the Warsaw Pact forces. In the 1976 FM 100-5, the stated purpose of military operations was to "destroy enemy military forces, and secure and defend important geographic objectives." The Army's purpose was to "win the land battle - to fight and win in battles, large or small, against whatever foe, wherever sent to war." However, more narrowly, the main purpose as the Army saw it was in the third chapter of 1976

${ }^{102}$ Mark Calhoun, interviewed by author, Fort Leavenworth, KS, February 5, 2013. Dr. Schifferle recommended an interview with Dr. Calhoun to garner additional perspectives on the relationship of history, theory and doctrine development. Dr. Calhoun was contacted via email on January 30, 2013. The discussion focused on the causes of the evolution of the FM 100-5 from 1976 to 1986 and on the roles key individuals like DePuy played then compared to General Dempsey's influence on the ADP 3-0. Dr. Calhoun conducted the interview with full understanding that his views would be directly attributed to him. 
FM 100-5 focused explicitly on "battle in Central Europe against the forces of the Warsaw Pact." 103

The prescriptive nature of the 1976 FM 100-5 did comprise a system designed to achieve the explicit purpose in the third chapter. Similarly, for the 1982 and 1986 editions of FM 100-5 the Army's purpose was to deter war while being ready to wage war and win should deterrence fail. The primary threat continued to be the Soviets and Warsaw Pact; however, the Army also recognized and acknowledged the possibility of other lesser threats worldwide. The collection of ideas and the more descriptive nature of the 1982 and 1986 FM 100-5 also comprised a system designed to enable Army leaders to achieve the purpose of deterrence as well as fight and win in the spectrum of conflict from low intensity to high intensity.

In answering the second and third questions for utility of the theory, the 1976 FM 100-5 fell short because of its narrow focus. The 1976 operations doctrine interpreted past events to guide the actions against only one possible threat and explicitly assumed that all other possible threats would be similar. "We cannot know when or where the U.S. Army will again be ordered into battle, but we must assume the enemy we face will possess weapons generally as effective as our own. And we must calculate that he will have them in greater number than we will be able to deploy, at least at the opening stages of a conflict." ${ }^{\text {104 }}$ Additionally, the 1976 FM 100-5 did not explicitly address the strategic objectives; implicitly the doctrine indicated the Army would meet strategic objectives by winning the land battle. Therefore, to answer the third question for the theory's utility the answer is weakly affirmative if the only strategic objective for the Army was to defeat the Soviets and Warsaw Pact.

${ }^{103}$ U.S. Department of the Army, 1976 FM 100-5, Change 1, 1-2 and 3-1.

${ }^{104}$ U.S. Department of the Army, 1976 FM 100-5, Change 1, 1-1. According to the 1976 operations manual the primary purpose of the Army was to win the land battle. 
The 1982 and 1986 FM 100-5 more favorably answered the second and third questions.

First, the 1982 edition proved more effective in interpreting events because it was not prescriptive in nature, tended to describe principles and ideas of warfare in general, and emphasized the importance of offensive operations. Similarly, the 1986 edition expanded the realm of possibilities for interpretation by emphasizing more than before the human element, leadership and the sublime, as well as acknowledging a potential spectrum of conflict that the Army should prepare for as opposed to focusing on Central Europe. The 1982 and 1986 FM 100-5 were more effective for interpreting events and guiding action and connecting tactical actions with strategic purposes.

All three editions of FM 100-5 met the theory evaluation criteria derived from Swain's article "Filling the Void." However, the linear relationship espoused by the CGSC model of history, theory and doctrine was indeterminate. It was evident throughout the three editions of $F M$ 100-5 analyzed that history, in the form of study, personal experiences, and lessons learned, was an influencing factor in the operations doctrine development. Theory, in Reynolds causal form and not an overarching theory but a collection of ideas, had a more prominent role in the 1982 and 1986 editions than in the 1976 FM 100-5. The relationship then between history, theory and doctrine became evident as an iterative, organic process that reflected how the Army thought about the nature of future war as pointed out by Dr. Calhoun. ${ }^{105}$

\section{A WAY FORWARD}

However, doctrine is not about study; it is a guide to application. The operational art codified in any doctrine, to include ADP 3-0, is a simplified guide to the application of theory in a practical, adaptive way by leaders at all echelons. The doctrine is derived from the theory, but it is not synonymous with the theory.

- Dr. Thomas Bruscino, SAMS Faculty $2012^{106}$

\footnotetext{
${ }^{105}$ Mark Calhoun, interviewed by author, Fort Leavenworth, KS, February 5, 2013.

${ }^{106}$ Thomas Bruscino, "The Theory of Operational Art and Unified Land Operations,"
} 
The Army does not have a doctrine derived from an overarching military theory but history, theory, and personal experiences are all influencing factors. The relationship between history, theory and doctrine development for the U.S. Army operations doctrine today is an iterative, organic process that does not yield an overarching theory of war. The U.S. Army engages in implementing best practices and lessons learned. The resulting Army doctrine is comprised of a compilation of best practices and numerous war theorists' ideas that have endured including du Picq, de Saxe, Clausewitz, Jomini, and Delbruck. Clausewitz and Jomini’s war theories have had a prominent influence on U.S. Army operations doctrine. Parallels between the U.S. Army's principles of war and Jomini's principles of war are evident in U.S. Army operations doctrine. Clausewitz's influence on U.S. Army officers and operations doctrine became noticeable after the publication of the English translation of On War by Michael Howard and Peter Paret in 1976. Ideas drawn from Clausewitz include those that emphasize the human dimension of warfare (what de Saxe called the sublime), friction, center of gravity and culminating point. ${ }^{107}$

There is scant evidence that explicitly illustrates a relationship between history, theory and doctrine development as articulated by the CGSC model. However, military professionals should not dismiss the role of the study of military history, military theorists and their corresponding theories given how much each has contributed to the development of professional military thought. The study of military history, military theorists and their corresponding theories helps military professionals gain an understanding of the foundations of their profession. Lessons

School of Advanced Military Studies Theoretical Paper (Summer 2012), 2.

${ }^{107}$ The term sublime comes from Azar Gat, A History of Military Thought: From the Enlightenment to the Cold War (New York. NY: Oxford University Press, 2001), 35. The U.S. Army 1986 Field Manual 100-5, in Appendix B the authors present the concepts of center of gravity, and culminating point out that these concepts are not new, rather they have not been explicitly discussed "for some time." 
and theories that help form Army doctrine derive from multiple sources including military history, warfare theorists, and military professionals' personal experiences. The theories alluded to are those that fit our definition of theory as a set of abstract ideas considered part of the warfare body of knowledge in Reynolds' causal form. ${ }^{108}$ Doctrine then becomes the textbook for the art and science of warfare in which military theories, once accepted by the profession, are articulated.

The simplistic CGSC model does not hold true. Reality shows this process involving history, theory, and doctrine is more complicated. A broadly accepted theory of warfare is not easily arrived at and there is little empirical evidence to demonstrate the existence of such a theory. No single theory, historical example, or an individual's personal experiences can illuminate the potential nature of future warfare. Jomini and Clausewitz exemplify the latter assertion. ${ }^{109}$ Jomini and Clausewitz formulated their individual theories of war from their personal experiences and observations of Napoleonic warfare, but neither the French nor the Prussian armies broadly accepted the theory. However, parts of both Jomini's and Clausewitz's theories have been incorporated into United States, German, French, and Russian military doctrine. Not a broad theory but a systemic collection of theories about the nature of future armed conflict can assist the U.S. Army in making the transition from a period of war to a period of preparing for the next war. Using theory as a tool to stimulate critical thinking rather than a

${ }^{108}$ Reynolds, Primer for Theory Construction, 10-11.

${ }^{109}$ Scott Gorman, interviewed by author, Fort Leavenworth, KS, February 5, 2013. Dr. Schifferle recommended an interview with Dr. Gorman to garner additional perspectives on the relationship of history, theory and doctrine development. Dr. Gorman was contacted via email on January 30, 2013. The discussion during the interview focused on potential sources to elucidate the history, theory, and doctrine relationship. Dr. Gorman pointed out that there was scant evidence in history to illustrate that one overarching theory of war was in use. A main point, Clausewitz and Jomini both developed two different theories from observing Napoleon. Dr. Gorman conducted the interview with full understanding that his views would be directly attributed to him. 
prescriptive guide for action elucidates the significance of the relationship between history, theory and doctrine if such relationship exists.

The Army does not have or share an explicit theory of war that will help prepare the Army to face future threats. However, the lack of an overarching theory of war is not alarming since there is little evidence that the Army relies on theory development to compose its operations doctrine. Rather the U.S. Army has demonstrated a propensity to develop its operations doctrine from history, in the form of study, personal experiences, individuals' ideas and lessons learned. This is most evident in the Chief of Staff of the Army's statement that the Army will move forward continuing to apply lessons learned to evolving threats. This method of applying lessons learned is not an anomaly. Application of best practices and lessons learned encompass a tradition in the Army as was highlighted in the analysis of FM 100-5 from 1976 to 1986. Rather the use of theory, as a set of abstract ideas, for military professionals is a means to stimulate critical thinking. Military professionals can articulate the findings of their critical examination of warfare, past and present, in doctrine based on the ideas they formulate. The synthesis of history (studied and personal experience), and military theory to help develop doctrine is not linear but rather an iterative process.

Because the Army's concept for future warfare does not identify either an explicit threat focus or theory, does not imply the Army will be ill prepared to meet future challenges. The Army may continue to find itself in a situation trying to prepare for every possible threat scenario from low-intensity to high-intensity conflict and variations in between. With limited resources in an era of decreasing budgets the Army will need to assume risk commensurate with the requirements levied against it. No matter what the Army prepares for it will be wrong because of the usual dynamics of friction and chance in warfare. The challenge as Michael Howard pointed out is for the Army not to be so wrong that it cannot quickly adapt. The Army's operations doctrine must strike a balance, as the 1986 FM 100-5 did, such that military professionals can 
effectively interpret events, guide action and connect tactical actions with strategic purposes to continue to achieve positions of relative advantage. 


\section{BIBLIOGRAPHY}

Audi, Robert, ed. The Cambridge Dictionary of Philosophy. New York: Cambridge University Press, 1995.

Baily, Desmond V. "Recognizing Signposts: Anticipating the Future Role of the Corps." Fort Leavenworth, KS: School of Advanced Military Studies U.S. Army Command and General Staff College, 2011.

Bellamy, Chris. The Future of Land Warfare. New York: St. Martin's Press, 1987.

Bruscino, Thomas. "The Theory of Operational Art and Unified Land Operations," School of Advanced Military Studies Theoretical Paper, Summer 2012.

Buley, Benjamin. The New American Way of War: Military Culture and the Political Utility of Force. New York, NY: Routledge, 2008.

Calhoun Mark. "Clausewitz and Jomini: Contrasting Intellectual Frameworks in Military Theory," Army History 80, Washington DC, Summer 2011.

Clausewitz, Carl von. On War. Ed. and trans. Michael Howard and Peter Paret. Princeton: University Press, 1989.

Cohen, Eliot A. Military Misfortunes: The Anatomy of Failure in War. New York: Vintage Books, 1991.

Collins, Mark D. Creating Cultural Skills Capability within Conventional Force Leaders. Fort Leavenworth, KS: School of Advanced Military Studies U.S. Army Command and General Staff College, 2011.

Craig, Gordon A. "Delbrück: The military Historian," in Peter Paret, Gordon A. Craig, and Felix Gilbert, eds., Makers of Modern Strategy: from Machiavelli to the Nuclear Age. Princeton, N.J.: Princeton University Press, 1986. 326-353.

Curran Robert J. "Shutting the Door: U. S. Army Doctrine for Encirclement/Envelopment Operations at the Operational Level of War." Fort Leavenworth, KS: School of Advanced Military Studies U.S. Army Command and General Staff College, 1986.

Czege, Huba Wass de. "How to Change an Army." Military Review 77 (Jan/Feb 1997): 162-173.

Czege, Huba Wass de and Holder,L.D. “The New FM 100-5.” Military Review 62 (July 1982): 53-70.

Delbrück, Hans. History of the Art of War, Volume IV: The Dawn of Modern Warfare. Lincoln, Neb.: University of Nebraska Press, 1990.

Doughty, Robert A. “The Evolution of U.S. Army Tactical Doctrine, 1946-1976.” Leavenworth Papers 1. Fort Leavenworth, KS: August 1979.

Gaddis, John L. The Landscape of History. Oxford, NY: Oxford University Press, 2002.

Gaddis, John Lewis. The United States and the End of the Cold War: Implications, Reconsiderations, Provocations. New York: Oxford University Press, USA, 1992.

Galloway, Archie. “FM 100-5: Who Influenced Whom?” Military Review 66 (Mar 1986), 46-51.

Gat, Azar. A History of Military Thought: From the Enlightenment to the Cold War. New York, NY: Oxford University Press, 2001.

Hall, Wayne M. “A Theoretical Perspective of Airland Battle Doctrine.” Military Review 66 (Mar 1986), 32-43. 
Harrison, Richard W. Architect of Soviet Victory in World War II: The Life and Theories of G.S. Isserson. Jefferson, NC: McFarland \& Company, Inc., 2010.

Herbert, Paul H. Deciding What Has to be Done: General William DePuy and the 1976 Edition of FM 100-5, Operations. Fort Leavenworth, KS: Combat Studies Institute, 1988.

Lebovic, James H. "How Organizations Learn: U.S. Government Estimates of Foreign Military Spending." American Journal of Political Science 39, no. 4 (Nov. 1995): 835-63.

Liddell Hart. Strategy. New York: New American Library, 1974.

Long Jeffrey W. "The Evolution of U.S. Army Doctrine: From Active Defense to Airlnad Battle and Beyond." Fort Leavenworth, KS: U.S. Army Command and General Staff College, 1991.

Isserson, G.S. "The Evolution of Operational Art," Translated by Bruce W. Menning. Fort Leavenworth, KS: SAMS Theoretical Special Edition, 2005.

Kipp, Jacob, and Lester Grau. "Military Theory, Strategy, and Praxis.” Military Review 91, no. 2 (Mar/Apr 2011): 12-22.

Krepinevich, Andrew F. The Army in Vietnam. Baltimore: Johns Hopkins University Press, 1986.

Kretchik, Walter E. U.S. Army Doctrine: From the American Revolution to the War on Terror. Lawrence: University Press of Kansas, 2011.

Kuhn, Thomas S. The Structure of Scientific Revolutions. 3rd ed. Chicago, IL: The University of Chicago Press, 1996.

Linn, Brian McAllister. The Echo Battle: The Army's War. Cambridge: Harvard University Press, 2007.

Long, Jeffrey W. "The Evolution of U.S. Army Doctrine: From Active Defense to Air Land Battle and Beyond." Fort Leavenworth, KS: U.S. Army Command and General Staff College, 1991.

Luttwak, Edward N. Strategy: the Logic of War and Peace. Rev. and enl. ed. Cambridge, Mass.: Belknap Press of Harvard University Press, 2002.

Luvaas, Jay. The Education of an Army. Chicago: University of Chicago Press, 1964.

. "Some Vagrant Thoughts on Doctrine.” Military Review 66 (Mar 1986), 56-60.

Matheny, Michael R. Origins of Modern American Operational Art. 2007.

_ . "Development of the Theory and Doctrine of Operational Art in the American Army, 1920-1940.” Fort Leavenworth, KS: U.S. Army Command and General Staff College, 1988.

- Carrying the War to the Enemy: American Operational Art to 1945. Norman: University of Oklahoma Press, 2011.

Millett, Allan R., and Peter Maslowski. For the Common Defense: A Military History of the United States of America. New York: Free Press, 1984.

Millet, Allan R., and Williamson Murray, eds. Military Effectiveness, Volume I: The First World War. Boston: Allen and Unwin, 1988.

-. Military Effectiveness, Volume II: The Interwar Period. Boston: Allen and Unwin, 1988.

- Military Effectiveness, Volume III: The Second World War. Boston: Allen and Unwin, 1988. 
Munro, Jennifer A. "Transforming the Army Division in an Era of Persistent Conflict." Fort Leavenworth, KS: School of Advanced Military Studies U.S. Army Command and General Staff College, 2009.

Murray, Williamson. Military Adaptation in War: With Fear of Change. New York: Cambridge University Press, 2011.

. and Richard Hart Sinnreich, eds. The Past as Prologue: the Importance of History to the Military Profession. New York: Cambridge University Press, 2006.

. National Security Challenges for the 21 st Century. Carlisle Barracks, PA: Strategic Studies Institute, U.S. Army War College, 2003.

- A Nation at War in an Era of Strategic Change. Carlisle Barracks, PA: Strategic Studies Institute, U.S. Army War College, 2004.

- The Iraq War: A Military History. Cambridge, MA: Belknap Press of Harvard University Press, 2003.

- Transformation Concepts for National Security in the 21st Century. Carlisle Barracks, PA: Strategic Studies Institute, U.S. Army War College, 2002.

- Army Transformation: A View from the U.S. Army War College. Carlisle, PA: Strategic Studies Institute, U.S. Army War College, 2001.

- The Emerging Strategic Environment: Challenges of the Twenty-First Century. Westport, CT: Praeger, 1999.

Naveh, Shimon. In Pursuit of Military Excellence: The Evolution of Operational Theory. Portland, OR: Frank Cass, 1997.

Nichiporuk, Brian. Information Technologies and the Future of Land Warfare. Santa Monica, CA: Rand, 1995.

Paret, Peter. Makers of Modern Strategy: From Machiavelli to the Nuclear Age. Princeton, NJ: Princeton University Press, 1986.

Peters, Ralph. Beyond Terror: Strategy in a Changing World. Mechanicsburg, PA: Stackpole Books, 2002.

Reardon, Carol. Soldiers and Scholars: The U.S. Army and the Uses of Military History, 18651920. Lawrence, KS: University Press of Kansas, 1990.

Reynolds, Paul Davidson. A Primer for Theory Construction. Boston, MA: Allyn \& Bacon, 1971.

Richardson,William R. "FM 100-5: The Airland Battle in 1986.” Military Review 66 (Mar 1986), 4-11.

Romjue, John L. From Active Defense to Air Land Battle: the Development of Army Doctrine 1973-1982. Fort Monroe, VA: United States Army Training and Doctrine Command, 1984.

_. "Airland Battle: the Historical Background." Military Review 66 (Mar 1986), 52-55.

Rosen, Stephen P. Winning the Next War: Innovation and the Modern Military. Ithaca: Cornell University Press, 1991.

Saxe, Maurice de. My Reveries Upon the Art of War. In Thomas R. Phillip, The Roots of Strategy, Book I. Mechanicsburg, PA: Stackpole Books, 1985.

Schelling, Thomas. C. Arms and Influence. New Haven: Yale University Press, 2008. 
Schifferle, Peter J. America's School for War: Fort Leavenworth, Officer Education, and Victory in World War II. Lawrence, KS: University Press of Kansas, 2010.

Schneider, James J. Vulcan's Anvil: The American Civil War and the Foundation of the Operational Art. Theoretical Paper No. 4. Fort Leavenworth, KS: U.S. Army Command and General Staff College, 2004.

Simpkin, Richard E. Race to the Swift: Thoughts on Twenty-First Century Warfare. London: Brassey's Defence Publishers, 1985.

Steele, Matthew. “The Conduct of War.” Lecture, Department of Military Art, Army Staff College, Fort Leavenworth, KS, 1907.

Summers, Harry G. On Strategy: A Critical Analysis of the Vietnam War. Novato, CA: Presidio Press, 1995.

Swain, Richard M. "Filling the Void: The Operational Art and the U.S. Army." In Operational Art: Developments in the Theory of War, edited by B.J.C. McKercher and Michael Hennessy. Westport, CT: Praeger, 1996.

Weigley, Russell F. The American Way of War: A History of United States Military Strategy and Policy. Bloomington, IN: Indiana University Press, 1977

Wilson, Jeffrey S. “Transformational Leadership: William DePuy's Vision for the Army." Military Review140, no. 5 (Sep/Oct 2011): 70-77.

Willbanks, James H. U.S. Army Command and General Staff College, H100 Rise of the Western Way of War Parallel Block. Fort Leavenworth, KS: USACGSC, 2011.

Wittner, Lawrence. "The Nuclear Freeze and Its Impact.” Arms Control Association. http://www.armscontrol.org/act/2010_12/LookingBack (accessed December 10, 2012).

Schön, Donald A. Educating The Reflective Practitioner: Toward a New Design for Teaching and Learning in the Professions. San Francisco: Jossey-Bass, 1990.

U.S. Department of the Army, Army Doctrinal Publication 1, The Army. Washington, DC: Government Printing Office, September 2012.

. Army Doctrinal Publication 3-0, Unified Land Operations. Washington, DC:

Government Printing Office, October 10, 2011.

- Army Doctrine Reference Publication 3-0, Unified Land Operations. Washington, DC: Government Printing Office, May 16, 2012.

—. Field Manual 3-0, Operations. Washington D.C.: U.S. Government, July 1, 1976.

—. Field Manual 100-5, C1, Operations. Washington D.C.: U.S. Government, July 1, 1976.

—. Field Manual 100-5, Operations. Washington D.C.: U.S. Government, August 22, 1982.

—. Field Manual 100-5, Operations. Washington D.C.: U.S. Government, May 5, 1986.

—. Field Manual 100-5, Operations. Washington D.C.: U.S. Government, June 14, 1993.

—. Field Manual 3-0, Operations. Washington D.C.: U.S. Government, June 14, 2001.

—. Field Manual 3-0, Operations. Washington D.C.: U.S. Government, February 27, 2008. 
—. Field Manual 3-0, C1, Operations. Washington D.C.: U.S. Government, February 22, 2011.

- TRADOC PAM 525-66, Force Operating Capabilities. Fort Monroe, VA: Training and Doctrine Command, March 7, 2008.

- TRADOC PAM 525-2-1, The United States Army Functional Concept for Intelligence 2016-2028. Fort Monroe, VA: Training and Doctrine Command, October 13, 2010.

- TRADOC PAM 525-3-0, The United States Army Capstone Concept 2016-20128. Fort Monroe, VA: Training and Doctrine Command, December 21, 2009.

- TRADOC PAM 525-3-1, The United States Army Operating Concept. Fort Monroe, VA: Training and Doctrine Command, August 19, 2010.

- TRADOC PAM 525-100-1, Leadership and Command on the Battlefield. Fort Monroe, VA: Training and Doctrine Command, 1992.

- TRADOC PAM 525-100-2, Leadership and Command on the Battlefield: Battalion and Company. Fort Monroe, VA: Training and Doctrine Command, 1993.

- TRADOC PAM 525-100-4, Leadership and Command on the Battlefield: Noncommissioned Officer Corps. Fort Monroe, VA: Training and Doctrine Command, 1994.

- TRADOC PAM 525-5, Force XXI Operations. Fort Monroe, VA: Training and Doctrine Command, August 1994.

—. TRADOC Regulation 10-5, Organization and Functions. Fort Monroe, VA: Training and Doctrine Command, June 28, 1985.

U.S. Joint Chiefs of Staff, Joint Publication 1-02, Department of Defense Dictionary of Military and Associated Terms. Washington D.C.: Government Printing Office, November 15, 2011.

\section{$\underline{\text { Interviews }}$}

Bruscino, Thomas. School of Advanced Military Studies Faculty. Interview by author, Fort Leavenworth, KS, February 7, 2013.

Calhoun, Mark. School of Advanced Military Studies Faculty. Interview by author, Fort Leavenworth, KS, February 5, 2013.

Gorman, Scott. Academic Director of the School of Advanced Military Studies. Interview by author, Fort Leavenworth, KS, February 5, 2013.

Kubiak, Jeffrey. School of Advanced Military Studies Faculty. Interview by author, Fort Leavenworth, KS, January 31, 2013.

Stanley, Bruce. School of Advanced Military Studies Faculty. Interview by author, Fort Leavenworth, KS, February 4, 2013. 